\title{
Dekomunizacja, czyli faszyzm bez faszystów \\ 0 faszyzacji przestrzeni rozmawiają Konrad Matyjaszek, Xawery Stańczyk, Marcin Starnawski, Katrin Stoll i Anna Zawadzka
}

\author{
Opracowała: Anna Zawadzka
}

Edynburg-Poznań-Warszawa-Wrocław

kwiecień-lipiec 2021

\begin{abstract}
Abstrakt: Czy są faszyzujące sposoby patrzenia na przestrzeń i na estetykę? Jeśli tak, to jak się manifestują? Czym charakteryzuje się faszyzacja przestrzeni? Jak i gdzie można ją rozpoznać? W jaki sposób architektura i symbole w przestrzeni publicznej przyczyniają się do faszyzacji życia codziennego? Jakie są narzędzia faszyzacji przestrzeni? Jedno z nich to polityka czystki oraz retoryka odzyskania przestrzeni po wyobrażonej obcej dominacji lub inwazji. Celem niniejszej rozmowy jest wyjaśnienie i rozświetlenie koncepcji faszyzacji przestrzeni. Dyskutantki i dyskutanci robią to, posiłkując się przykładami z historii i współczesności Polski i Niemiec. Zastanawiają się także nad możliwym doprecyzowaniem kategorii faszyzacji tak, by odróżnić ten proces od innych zjawisk, np. nacjonalizmu.

Wyrażenia kluczowe: faszyzm; faszyzacja; organizacja przestrzeni; antykomunizm; Polska; Niemcy
\end{abstract}

Katrin Stoll: Od pewnego czasu mamy do czynienia z otwartą destrukcją demokracji, kultury i nauki. Proces faszyzacji, przyspieszany i wspierany przez kapitalizm oraz „transnarodowy polityczny projekt neoliberalizmu” (Wacquant, 2014, s. 1691), dotyczy też przestrzeni - m.in. prywatnej (ciał kobiet), państwowej, miejskiej, dzielnicowej, osiedlowej oraz wiejskiej.

Walka o zdobycie przestrzeni i terytorium jest centralną kategorią prawicowego myślenia. Nazistowska interpretacja koncepcji Lebensraum oznaczała Todesraum (przestrzeń śmierci) dla europejskich Żydów oraz radzieckich jeńców wojennych. Prawicowi aktorzy systematycznie tworzyli i tworzą przestrzeń, w której wszyscy postrzegani jako „inni” i „obcy” są otwarcie prześladowani, nie mogą czuć się bezpiecznie albo znajdują się w pozycji sublokatorstwa, bez równych praw. Zamiast różnorodności i wielojęzyczności ma być homogenizacja i jednojęzyczność. Prawica dąży do zbudowania stref wolnych od ludzi niechcianych, przedstawianych jako nieludzie i zbytecznych. (W języku niemieckim neonazistów: national befreite Zonen).

Czy są faszyzujące sposoby patrzenia na przestrzeń i na estetykę? Jeśli tak, to jak się manifestują? Czym charakteryzuje się faszyzacja przestrzeni? Jak i gdzie można ją roz-

SLH 10/2021 | s.1 z 34 
poznać? W jaki sposób architektura i symbole w przestrzeni publicznej przyczyniają się do faszyzacji? Czy społeczeństwo rasistowskie i „kultura antysemicka” (Janicka, 20142015, ss. 165-168) w kapitalizmie produkują specyficzną strukturę miast i wsi? Jeżeli tak, to jakie są ich charakterystyczne cechy? Po czym można odróżnić faszyzację przestrzeni od produkowania hegemonii? O ustanawianiu hegemonii grupy dominującej w polskiej przestrzeni publicznej pisał Konrad Matyjaszek w swojej książce Produkcja przestrzeni żydowskiej w dawnej i wspótczesnej Polsce (Matyjaszek, 2019)².

Celem naszej rozmowy jest wyjaśnienie i rozświetlenie koncepcji faszyzacji przestrzeni. Zacznę od odróżnienia analitycznego pojęć „faszyzacji” i „faszyzmu”. Ważne wydaje mi się rozpoznanie Georga Seeßlena, że „faszyzm jako konstrukt i faszyzacja jako proces są dwiema różnymi rzeczami, które są ze sobą związane i jednocześnie różnią się od siebie" (Seeßlen, 2020). W stosunku do historycznego faszyzmu przytaczam tu definicję, którą podaje Enzo Traverso w swojej książce Historia jako pole bitwy (Traverso, 2014). Mówi on o „kulturze faszystowskiej” (Traverso, 2014, s. 111). Nawiązując do Georga Mossego, Zeeva Sternhella i Emilia Gentilego, Traverso pisze:

Czym więc był faszyzm? Chociaż każdy z tych trzech historyków dał swoją własną odpowiedź, to jednak wszyscy oni są zgodni co do definicji, koncentrującej się na kilku charakterystycznych, istotnych punktach: faszyzm byt razem rewolucją, ideologią, wizją świata i kulturą. Rewolucją, ponieważ chciał zbudować nowe społeczeństwo. Ideologią, ponieważ zdefiniował na nowo nacjonalizm w perspektywie, która - po odrzuceniu marksizmu - przeciwstawiła się zarówno konserwatyzmowi, jak i liberalizmowi, szukając drogi alternatywnej. Wizją świata, ponieważ wpisywał swój projekt polityczny w wizję historii, chciał stworzyć „nowego człowieka" i prezentował siebie jako opatrznościowe przeznaczenie narodu. A kulturą, ponieważ chciał przeobrazić świat zbiorowej wyobraźni, zmienić styl życia, znieść rozłam między życiem prywatnym a publicznym. Wszystkim trzem chodzi o „prawicową rewolucję”, której motorem społecznym były klasy średnie i której ambicją było zbudowanie nowej cywilizacji (Traverso, 2014, ss. 111-112).

Traverso zwraca uwagę, że w tej definicji brakuje wątku antykomunizmu: „Faszyzm nie istniałby bez antykomunizmu" (Traverso, 2014, s. 133). Podkreśla, że faszyzm jest zjawiskiem „kontrrewolucyjnym”, który był możliwy z powodu wsparcia i integracji tradycyjnych elit. Cytuję: „faszyzmy zawsze włączały do swojego systemu władzy dawne elity gospodarcze, administracyjne i wojskowe. Żaden ruch faszystowski nie doszedł do władzy bez poparcia, choćby zaocznie, tradycyjnych elit. [...] Philippe Burrin trafit w sedno, określając faszyzm jako «rewolucję bez rewolucjonistów»" (Traverso, 2014, s. 134).

1 Dyskutując pojęcie kultury antysemickiej Andrzeja Bryka (Bryk, 1990, ss. 171-172) oraz pojęcie „antysemickiego kodu społecznego” Marii Janion (Janion, 2009, s. 71), Elżbieta Janicka pisze: „W kategorii kultury antysemickiej chodziłoby jednak o coś więcej w tym sensie, że antysemityzm nie stanowi jedynie jednego z nurtów czy kodów owej kultury, lecz jest generatorem tożsamości wspólnoty - najpierw religijnej, następnie narodowej, ustanawianej według kryteriów etniczno-religijnych - będącej również wspólnotą aksjonormatywną" (Janicka, 2014-2015, s. 166).

2 Nawiązując do pracy Lefebvre’a, Konrad Matyjaszek pisze: „[Hegemonia] [w]ywierana jest za pomocą kultury i wiedzy, a również za pomocą produkowanej w tym celu miejskiej i społecznej przestrzeni, stającej się «środkiem kontroli, a więc i dominacji oraz władzy». Zaprowadzenie tej hegemonii powoduje osłonięcie procesów produkcji przestrzeni pożydowskiej dyskursywną zasłoną, powodującą niedostrzegalność zjawisk i procesów pozostających w obrębie językowo-przestrzennego kodu, komunikowanego przez przywrócony na plac Grzybowski porządek spekulacyjnego kapitalizmu” (Matyjaszek, 2019, s. 509). 


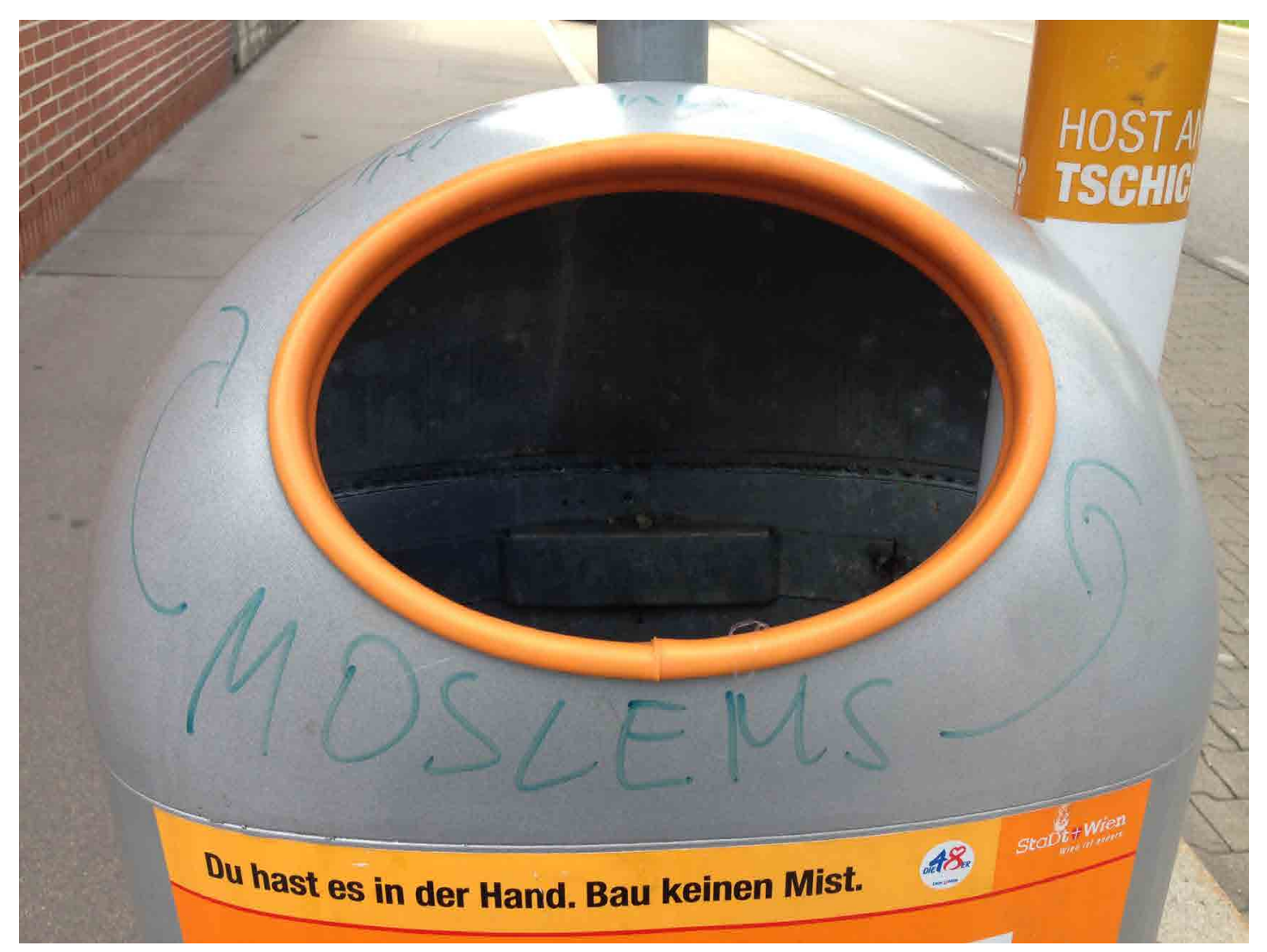

Fot. Alexia Weiss, Wiedeń, 1 czerwca 2017 roku (๔ Alexia Weiss, dzięki uprzejmości Autorki zdjęcia)

Patrząc na dzisiejszą sytuację, można zapytać, czy żyjemy w „demokracji bez demokratów”, jak twierdzi Georg Seeßlen (Seeßlen, 2020). Używa on terminu faszyzacja, aby opisać sytuację i tendencje w Europie i w innych miejscach na świecie. W ślad za Seeßlenem faszyzację można rozumieć jako „polityczno-kulturowy proces” (Seeßlen, 2020), który dzieje się w centrum państw i społeczeństw oraz który dąży do wykluczenia i wyeliminowania napiętnowanych grup ze społeczeństwa i z przestrzeni publicznej na zasadzie „Europy bez...”, „miasta bez...” (Die Stadt ohne, b.d.), „dzielnicy bez.... W ramach tego procesu aktorzy używają przemocy symbolicznej, ekonomicznej i fizycznej, aby dopasować rzeczywistość do prawicowego fantazmatu jedności grupy dominującej (np. narodu albo Volk), przestrzeni/terytorium i wspólnoty. W faszyzacji chodzi więc „o włączanie kultury, państwa i biografii do totalnej jedności” (Seeßlen, 2020).

Jakie są narzędzia faszyzacji przestrzeni? Jedno z nich to polityka oczyszczająca oraz retoryka odzyskująca po wyobrażonej obcej dominacji albo inwazji. W skali makro mamy do czynienia z demarkacją. Oto przykład: państwa narodowe w Europie, czyli Festung Europa, zacieśniają swoje granice i wykluczają tych, którzy uciekają przed wojnami oraz przed konsekwencją porządku globalnego kapitalizmu i kryzysu klimatycznego. W 2015 roku, podczas tzw. kryzysu uchodźców, redaktor naczelny niemieckiego dziennika „Die Welt” nazwał kanclerz Merkel „kanclerzem bez granic” (Metz \& Seeßlen, 2016, 
s. 134). W dyskursie publicznym mówiono o uchodźcach w retoryce ruchu i liczb. Była „fala uchodźców”, którą trzeba było zatrzymać albo ograniczyć. Było ich „za dużo”. Z tego wynika, że część musi zniknąć, że potrzebna jest segregacja, selekcja albo eliminacja.

Retoryka za dużo „obcych”, za dużo migrantów, za dużo „innych” (na przykład osób LGBT, non-Western residents; Agence France-Presse in Copenhagen, 2021) w danej przestrzeni jest integralną częścią myślenia prawicowego. Retoryka „za dużo” idzie w parze z retoryką „za mało dla nas i z nas” oraz z mechanizmem kozła ofiarnego. W 2018 roku minister spraw wewnętrznych Niemiec, Horst Seehofer (CSU) - nominowany przez kanclerz Merkel na to stanowisko - nazwał „kwestię migracji matką wszystkich problemów” („Innenminister Seehofer zu Migration”, 2018). Prawdziwą odpowiedzią na taką agresję byłoby uznanie migracji za prawo człowieka oraz przyznanie migrantom prawa do obywatelstwa (di Cesare, 2020). Wymagałoby to oddzielenia procedury uznania obywatelstwa od decyzji państwa narodowego.

O związku między klasą, państwem (polityką penalizacji) i etnicznością pisał Loïc Wacquant. Wprowadził do dyskursu termin „stygmatyzacji terytorialnej” (Wacquant, 2014, s. 1700).

Jest chyba więcej narzędzi faszyzacji przestrzeni.

Marcin Starnawski: Termin „faszyzacja” wydał mi się początkowo obiecujący. Na pewno angażujący emocjonalnie. Gdy jednak próbowałem go „ubrać” w ramy metodologiczne, napotkałem poważny problem. Brakuje mi operacyjnej definicji faszyzacji. Choćby luźnej, niepełnej. Czy faszyzacja przestrzeni byłaby typem faszyzacji w ogóle? A może jedynie jej przykładem? Czy na poziomie stosunków społecznych i świadomości zbiorowej faszyzacja przestrzeni jest procesem autonomicznym? Można analizować jakieś wytwory w przestrzeni - np. graffiti o charakterze faszyzującym. Wytwór ten będzie jednak zależny od dynamiki społecznej i politycznej.

Drugi problem to granice czasowe. O jakich ramach historycznych mówimy? Czy o całym okresie po drugiej wojnie światowej, ponieważ uznajemy, że powracanie faszyzmu zaczęło się zaraz po jego pokonaniu? A jeśli tak, to czy można ten proces stopniować? Czy może on nasilać się lub słabnąć? Stopniowalność pozwoliłaby m.in. ocenić skuteczność strategii defaszyzujących. Weźmy kontekst polski. Gdy myślimy o faszyzacji, to jako cezura nasuwa się rok 2015. Tyle że już prawie dwadzieścia lat temu autorka, która podpisała się jako Gimnazjalistka, przygotowała wystawę o rasistowskim graffiti we Wrocławiu. Pokazała na niej siedemdziesiąt z siedmiuset zdjęć zrobionych w okresie od maja do grudnia 2001 roku. Wystawie towarzyszyła publikacja listu otwartego Gimnazjalistki. Odpowiedział na niego prezydent Kwaśniewski³.

3 Na temat wystawy zob. Gimnazjalistka, 2002; Wełyczko, 2002. Wystawę otwarto pod koniec stycznia 2002 roku we wrocławskim schronisku dla matek z dziećmi „Betlejem”. List otwarty Gimnazjalistki ukazał się 13 marca 2002 roku na łamach „Trybuny”, a trzy dni później ten sam dziennik opublikował odpowiedź prezydenta Alek- 
Anna Zawadzka: W jak cudownych czasach żyliśmy, kiedy to prezydent Polski czuł się wywołany do odpowiedzi listem otwartym Gimnazjalistki, zaniepokojonej wszędobylstwem rasizmu i antysemityzmu. Dzisiaj jest to nie do pomyślenia.

M.S.: Gdy sięgam pamięcią jeszcze dalej, do pierwszej połowy lat dziewięćdziesiątych, tendencje faszyzujące były obecne we Wrocławiu już wtedy. Popularność subkultury skinheadów, częste przypadki przemocy neonazistów i nacjonalistów - to jest pamięć mojego pokolenia.

Czy faszyzacja przestrzeni jest rezultatem narastającej faszyzacji stosunków społecznych (np. przemocy czy dyskryminacji), czy może jest odwrotnie? Czy graffiti antysemickie, istniejące przez całe lata dziewięćdziesiąte, zintensyfikowały polski antysemityzm, który kulminował po 2015 roku [zwłaszcza na początku 2018 roku w związku z nowelizacją ustawy o Instytucie Pamięci Narodowej (dalej: IPN)]? Czy też oddziaływanie ekstremum prawicowego na mainstream i ostateczne wejście tego ekstremum do mainstreamu to były procesy niezależne? Powiązanie nie jest oczywiste.

Rewolucja, ideologia, wizja świata, kultura - wszystkie te czynniki można przypisać także ruchom radykalnie lewicowym. Faszyzm, jako ruch skrajnej prawicy, ma jednak jeszcze coś innego - antykomunizm. Zgadzam się z Traverso (Traverso, 2014), ale i z innymi badaczami, jak Borejsza (Borejsza, 1979), Eatwell (Eatwell, 1999) czy Griffiths (Griffiths, 2005), że ten czynnik był w faszyzmie zawsze bardzo istotny, choć, rzecz jasna, niewyjątkowy tylko dla tego nurtu. Wracając jednak do faszyzacji, czy mówimy o zjawisku zero-jedynkowym? A jeśli nie, to jak rozpoznać jego stopniowanie?

Wreszcie nurtuje mnie pytanie o podmiot procesu faszyzacji. Odpowiedź na nie pozwoliłaby skonstruować socjologiczno-politologiczny czy, co nawet ważniejsze, pedagogiczny model, zdefiniować praktyki opozycyjne, a także określić podmiot defaszyzacyjny. Współcześnie faszyści unikają nazywania siebie faszystami. Socjolożka Justyna Kajta przeprowadziła badania biograficzne członków ruchu narodowego. Dyskurs o faszystach to, zdaniem jej rozmówców - nacjonalistów, tożsamość „narzucana”. Tożsamość pożądana przez organizacje i odczuwana przez ich członków, tożsamość deklarowana, to: aktywni młodzi ludzie, przyszłe elity, intelektualiści, walczący o wolność, świadomi zagrożeń, ludzie kierujący się słusznymi wartościami, takimi jak Bóg, honor, ojczyzna i rodzina itd. (Kajta, 2020, s. 293). Co więcej, w Polsce nie odróżnisz już estetyki antyfaszystowskiej od skrajnie prawicowej, bo jedni i drudzy przynoszą na swoje manifestacje transparenty z przekreślonymi tymi samymi symbolami: sierpem i młotem, Che Guevarą i swastyką.

sandra Kwaśniewskiego (zob. List otwarty Prezydenta RP, 2002). Rok później wystawę fotografii Gimnazjalistki zorganizowało Centrum Kultury Żydowskiej w Krakowie (Czuchnowski, 2003). 
Konrad Matyjaszek: W krajach takich jak Polska podmiot faszystowski jest elitarny. Faszystami jawnymi są grupy walczące na ulicach, które zwykle uważamy za pochodzące z klas podporządkowanych. Ale produkowanie wykluczenia odbywa się gdzie indziej. Do tej produkcji potrzebna jest silna pozycja społeczna, prawo głosu, prawo do przestrzeni, prawo własności symbolicznej i materialnej. Faszyzm europejski jest zjawiskiem ciągłym, dlatego nie chcę patrzeć na niego przez pryzmat grup, które obecnie czerpią otwarcie z tradycji faszystowskiej. Interesuje mnie to, co wcześniej i dalej. Problem z zabiegami, które faszyzm dokonuje na przestrzeni, polega na tym, że faszyzm nie jest obsceniczny ani niecenzuralny. Obsceniczne są może faszystowskie napisy na murach, bo ich twórcy czasami używają niecenzuralnego języka, ale w obrębie kultury głównego nurtu faszyzm potrafi zachowywać się „kulturalnie” i wtedy już nikogo nie oburza. Przyzwyczailiśmy się do myślenia o faszyzmie jako ekscesie. Tymczasem on jest w domu, jest u siebie. Aby zilustrować sposób działania faszyzmu polskiego jako centralnej części polskiej przestrzeni publicznej, przedstawię historyczne studium faszyzacji przestrzeni dla polskiej kultury fundamentalnej i najbardziej prawomocnej, czyli Wawelu. Będzie to zatem wycieczka w głąb tej kultury.

Historia faszyzacji Wawelu zaczyna się od konkretnej osoby - faszysty i jednocześnie członka kulturalnej i naukowej polskiej elity. Wincenty Lutosławski był faszystą w sensie ścisłym. Filozof, swego czasu bardzo znany, badacz Platona, urodził się w 1863 roku we dworze w Drozdowie, majątku położonym mniej więcej pomiędzy Łomżą, Jedwabnem a Wizną.

Studiował w Rydze, Helsinkach, Londynie. Wynalazł metodę datowania pism Platona i to Platon przyniósł mu sławę (Lutosławski, 1897). Ważniejsze od badania starożytności było dla niego jednak wychowanie narodu polskiego i odbudowa polskiej niepodległości. Zajmował się metafizyką, "nauką o duszy, wędrówce dusz i koncepcją anamnezy” (Padoł, 1982, s. 57). Był członkiem Ligi Narodowej, bliskim przyjacielem Romana Dmowskiego, a także mistykiem. W 1893 roku wziął udział w Pierwszym Światowym Kongresie Religii w Chicago. Zetknął się tam z mistrzami indyjskimi, którzy wywarli na niego niemały wpływ. Od tej pory zajął się propagowaniem w Polsce aryjskiej sztuki jogi (Lutosławski, 1907, 1908, 1909). Jego ówczesne teksty wpłynęły potem na Jerzego Grotowskiego i jego metodę teatralną (Kolankiewicz, 1995, s. 130; Osiński, 1993, s. 25). Lutosławski był profesorem na Uniwersytecie w Wilnie, a od 1899 roku na Uniwersytecie Jagiellońskim w Krakowie, gdzie założył stowarzyszenie mistyczno-etyczno-patriotyczno-religijne Eleusis, które uznawane jest za zaczątek polskiego harcerstwa (Głowacka-Sobiech, 2003, ss. 23-24). Eleusis miało znaczyć: Wolni Wyzwoliciele Ludów. Lutosławski pisat:

W attyckiej świątyni w Eleusis, trzy tysiące lat temu, nauczano o nieśmiertelności duszy i wyższości ducha nad ciałem. Misteria eleuzyńskie wtajemniczały wybranych, za wykluczeniem bezbożników, i uczyły ich czystością zasłużyć na lepszy żywot niż doczesny. Miały one charakter narodowy: obcych nie dopuszczono, tylko attyckich obywateli. Na pamiątkę tego naj-

SLH 10/2021 | s. 6 z 34 


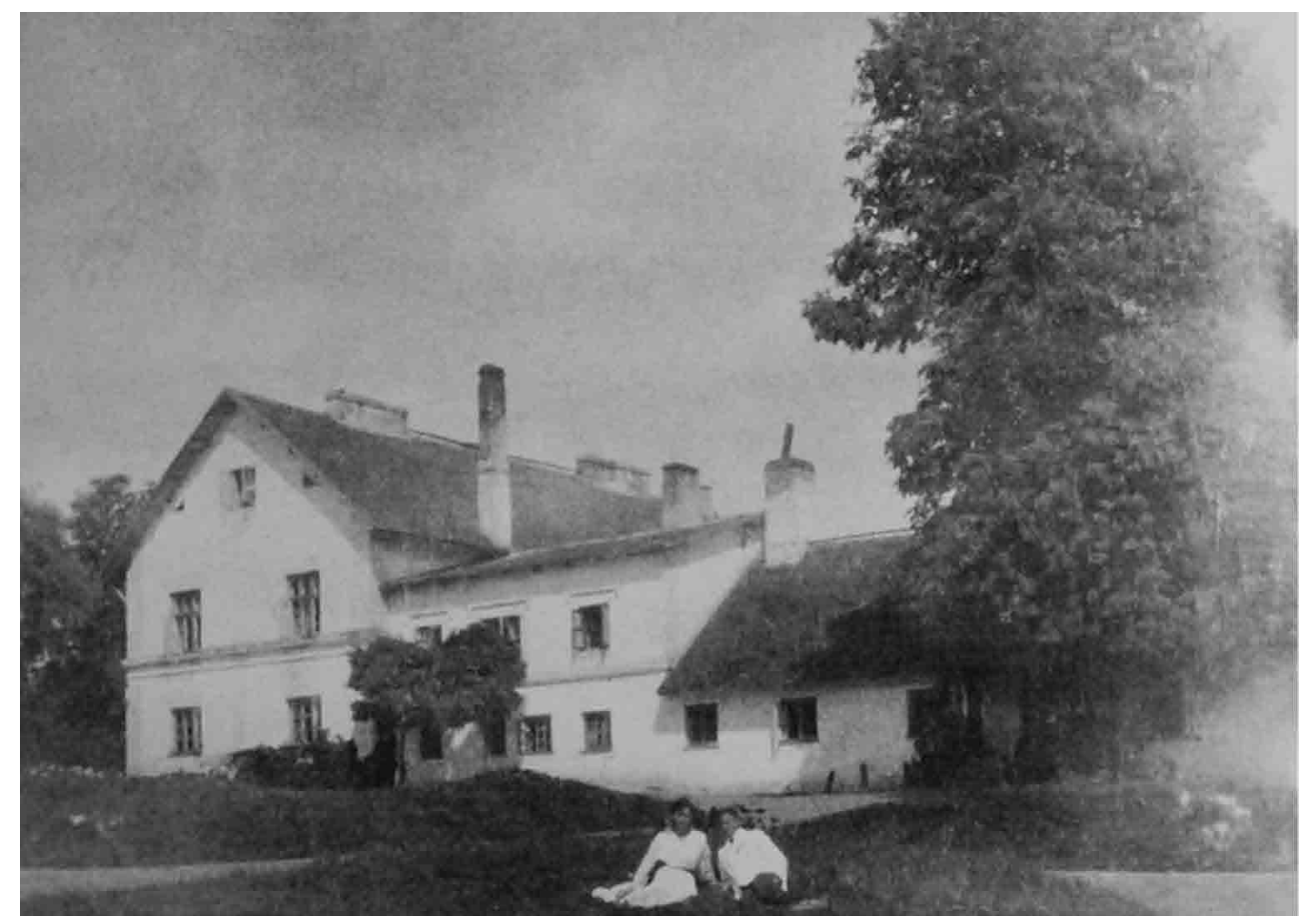

Dwór Lutosławskich w Drozdowie w Łomżyńskiem, koniec XIX wieku (ze strony: http://ziemianie. pamiec.pl/en/rody/lutoslawscy.html; domena publiczna)

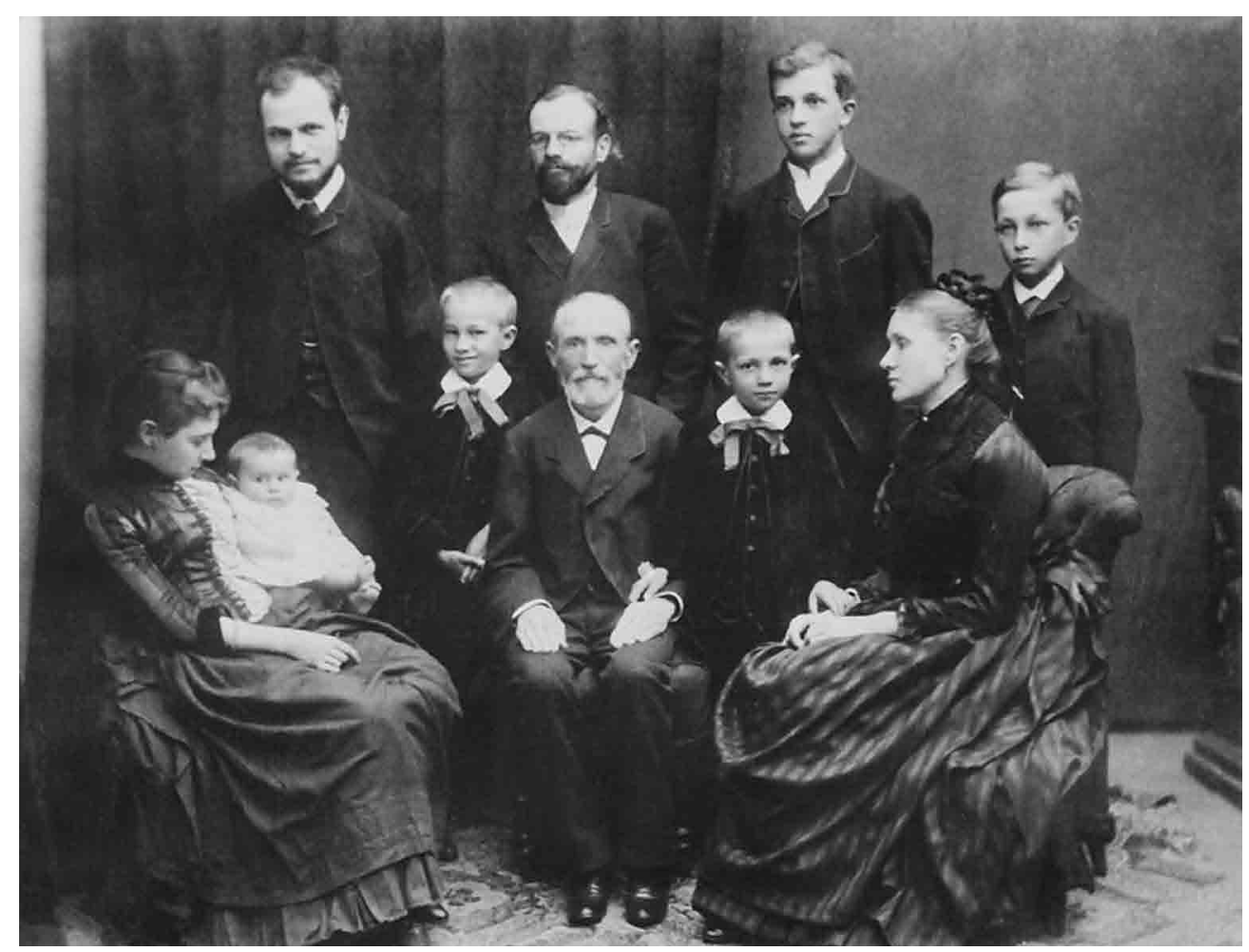

Rodzina Lutosławskich, 1888 r. Stoją (od lewej): Wincenty Lutosławski i jego bracia Stanisław, Marian, Jan. Siedzą (od lewej): Sofia Casanova z córką Marią, Kazimierz (brat Wincentego), Franciszek Dionizy (ojciec Wincentego, właściciel Drozdowa), Józef (brat Wincentego), Paulina ze Szczygielskich (druga żona Franciszka Dionizego) (ze strony: http://ziemianie.pamiec.pl/en/rody/lutoslawscy.html; domena publiczna) 
dawniejszego w Europie ogniska religijnego i narodowego odrodzenia nowe towarzystwo przyjęło starodawną grecką nazwę (Lutosławski, 1903, ss. 290-291).

Eleusis było więc stowarzyszeniem ascetyczno-katolickim, zajmującym się udoskonaleniem ciała i ducha przyszłego niepodległego narodu polskiego.

Lutosławski był mężem Sofii Casanovy, hiszpańskiej rojalistki, poetki, a później dziennikarki i reporterki wojennej. Gorącej zwolenniczki Franco. Kiedy oboje zamieszkali w Krakowie, Sofia prowadziła tam salon zwany „Hiszpanią”. Częstym jego gościem był Roman Dmowski. Córka Lutosławskiego i Casanovy, Maria Niklewicz, wspominała: „Ponieważ panu Romanowi nie służyło jadanie w pensjonacie, moja matka zaproponowała, aby jadał u nas, co weszło w zwyczaj" (Szostak, 2011).

Tę przestrzeń, przestrzeń prywatną, ów salon i dom Lutosławskich, najpierw w kamienicy przy placu Na Groblach 10 w Krakowie, a potem w willi na krakowskich Dębnikach przy ul. Szwedzkiej 10/2, nazwałbym przestrzenią faszyzacji w sensie ścisłym: to jest miejsce, w którym do czynności dochodziło. Na stronie internetowej starostwa powiatowego w Łomży, na którego terenie znajduje się dwór Lutosławskich, znaleźć można taki opis:

Lutosławski gromadził elitę polskich narodowców: Dmowskiego, Popławskiego, Balickich i wybitnych artystów: Wyspiańskiego, Mehoffera, Fałata, Stanisławskiego, Tetmajera, Reymonta, Rydla. Dziewczęta [córki], określane przez kolegów ojca „ofiarami endecji”, przysłuchiwały się tym nieustannym rozmowom o Polsce. Słuchał ich także, siedzący zawsze cichutko, Wyspiański, którego Wyzwolenie [dramat] zostało zainspirowane Myślami nowoczesnego Polaka odczytywanymi przez Dmowskiego na spotkaniach (Korwek, 2007).

O Stanisławie Wyspiańskim Konstanty Puzyna pisał: „Był to istotnie «niewolnik wielkiej myśli jednej»: myśli o wyzwoleniu narodowym. Bohaterstwo, kult życia i woli, walka z «losem historycznym», były u niego tylko pochodnymi tej myśli” (Puzyna, 19571958, s. 7). Labilność ideowa Wyspiańskiego ${ }^{4}$ sprawiła,że chłonął wszystko to, co usłyszał i o czym dyskutował w profesorskim salonie. I pociągnął te treści dalej, w stronę głównego nurtu kultury polskiej. Wieczorki dyskusyjne, w których uczestniczyt, miały miejsce w latach 1902-1904. W tym samym okresie Wyspiański pisze Wyzwolenie. Jednocześnie wraz z kolegą z pracy, architektem Władysławem Ekielskim, pracuje nad projektem rekonstrukcji Wawelu, który miało wówczas opuścić wojsko austro-węgierskie i który miał zostać zwrócony polskiemu narodowi. Wyspiański jest już wówczas chory, umiera w 1907 roku. Przygotowane wspólnie dzieło architektoniczne, projekt koncepcyjny Wawelu - polskiego Akropolis, Ekielski wyda już po śmierci Wyspiańskiego. Moim zdaniem projekt ten należy czytać w pakiecie z Wyzwoleniem, jako produkt dwójki „wolnych wyzwolicieli" działających według recept Lutosławskiego.

4 Pisze dalej Puzyna,że poza ideą „wyzwolenia narodowego”, dla Wyspiańskiego „resztę bagażu ideowego stanowiły właściwie pozostałości konstrukcji myślowych Słowackiego, Krasińskiego, tragików greckich, Homera, Wagnera - przypadkowe i często sprzeczne ze sobą. Długoletnie wieszczenie naszych polonistycznych Wernyhorów nad Wyspiańskim wywołało jednak zabawne zjawisko: bardzo nam trudno dzisiaj uwierzyć, że król jest nagi" (Puzyna, 1957-1958, s. 7). 


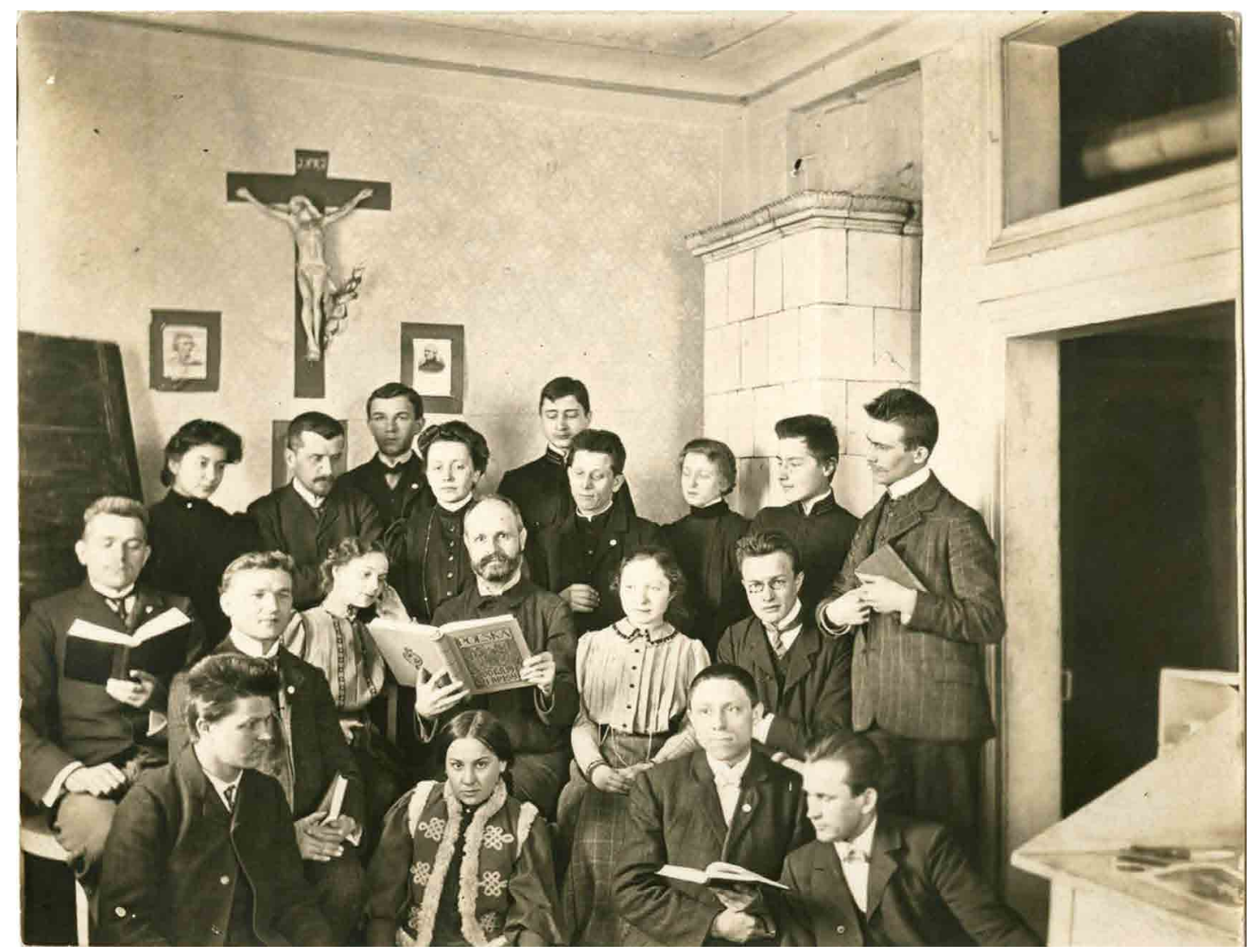

Wincenty Lutosławski z członkami Stowarzyszenia Eleusis, Kraków, 1906 (ze zbiorów Polskiej Akademii Umiejętności, http://pauart.pl/app/artwork?id=558a9a940cf2c6aee07b5449; domena publiczna)

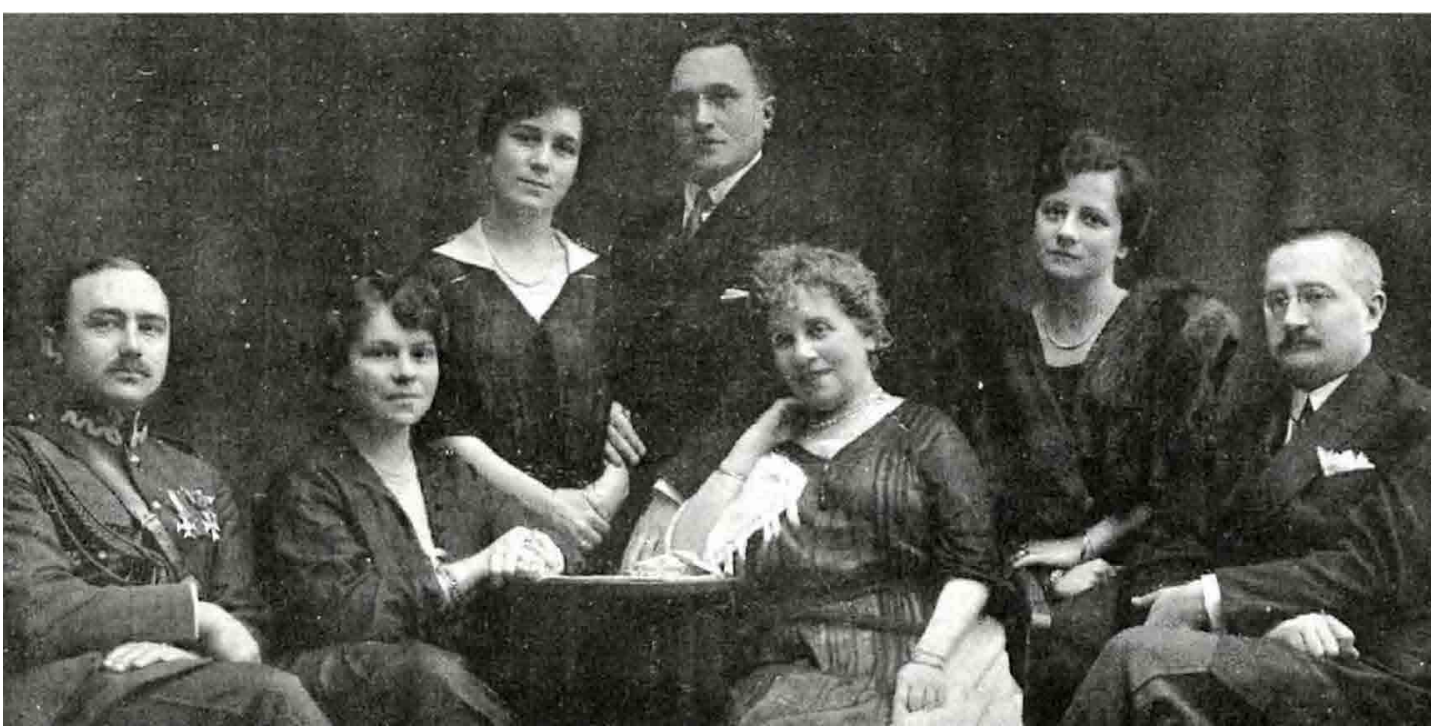

Sofia Casanova z córkami i ich mężami, ok. 1925 r. Od lewej: Romuald Wolikowski, Izabela Wolikowska, Maria Niklewicz, Mieczysław Niklewicz, Sofia Casanova, Halina Meissner, Czesław Meissner (ze zbiorów Biblioteca Nacional de España, http://hemerotecadigital.bne.es/issue.vm?id=0003265097\&page=16; domena publiczna) 


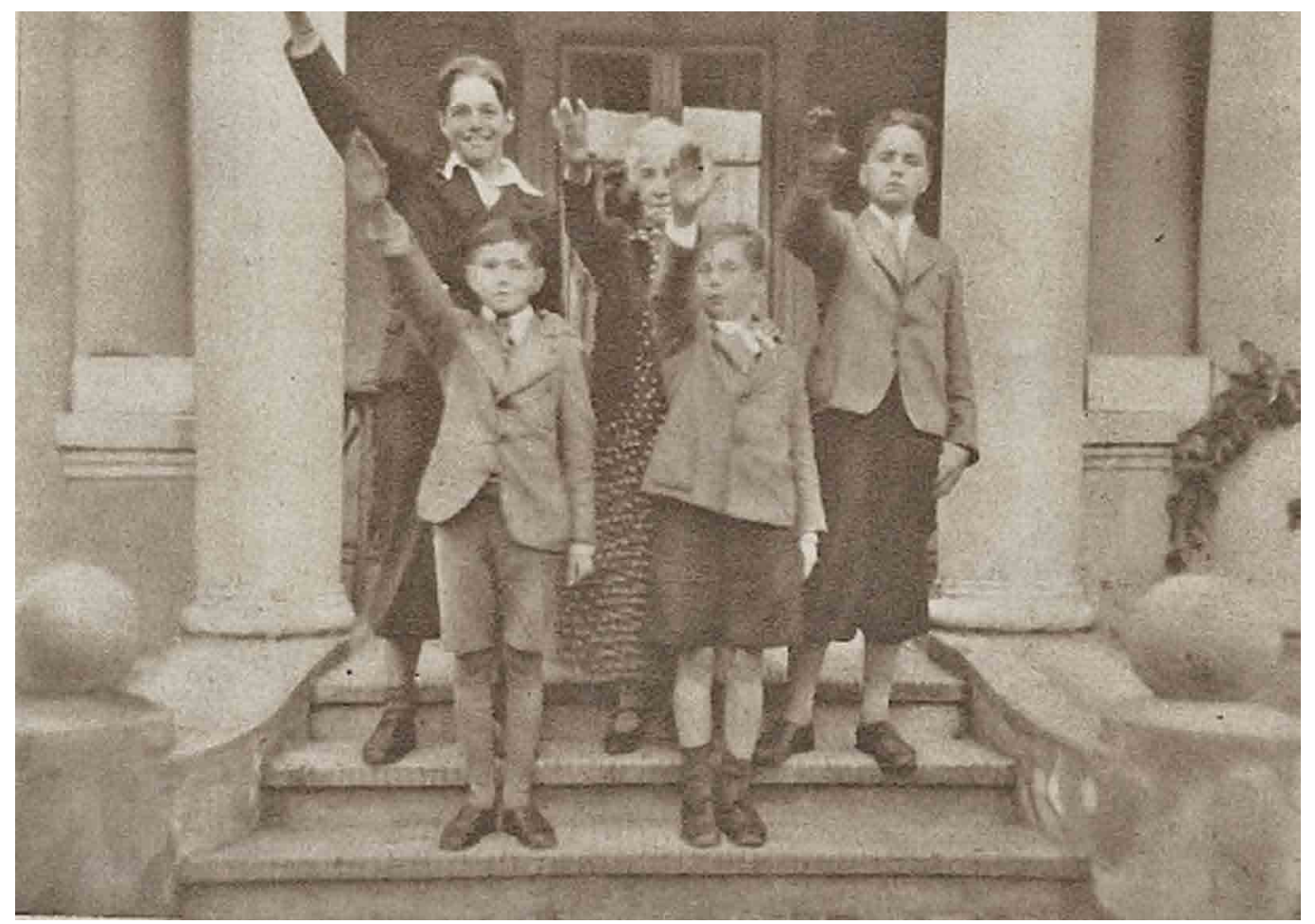

Sofia Casanova z wnukami, Poznań, 1938 (César Lorenzo Gil, O brazo ergueito de Sofía Casanova, https:// biosbardia.wordpress.com/2014/12/03/o-brazo-ergueito-de-sofia-casanova/

Przedruk z: Fotos. Semanario gráfico nacionalsindicalista, 1938; domena publiczna)

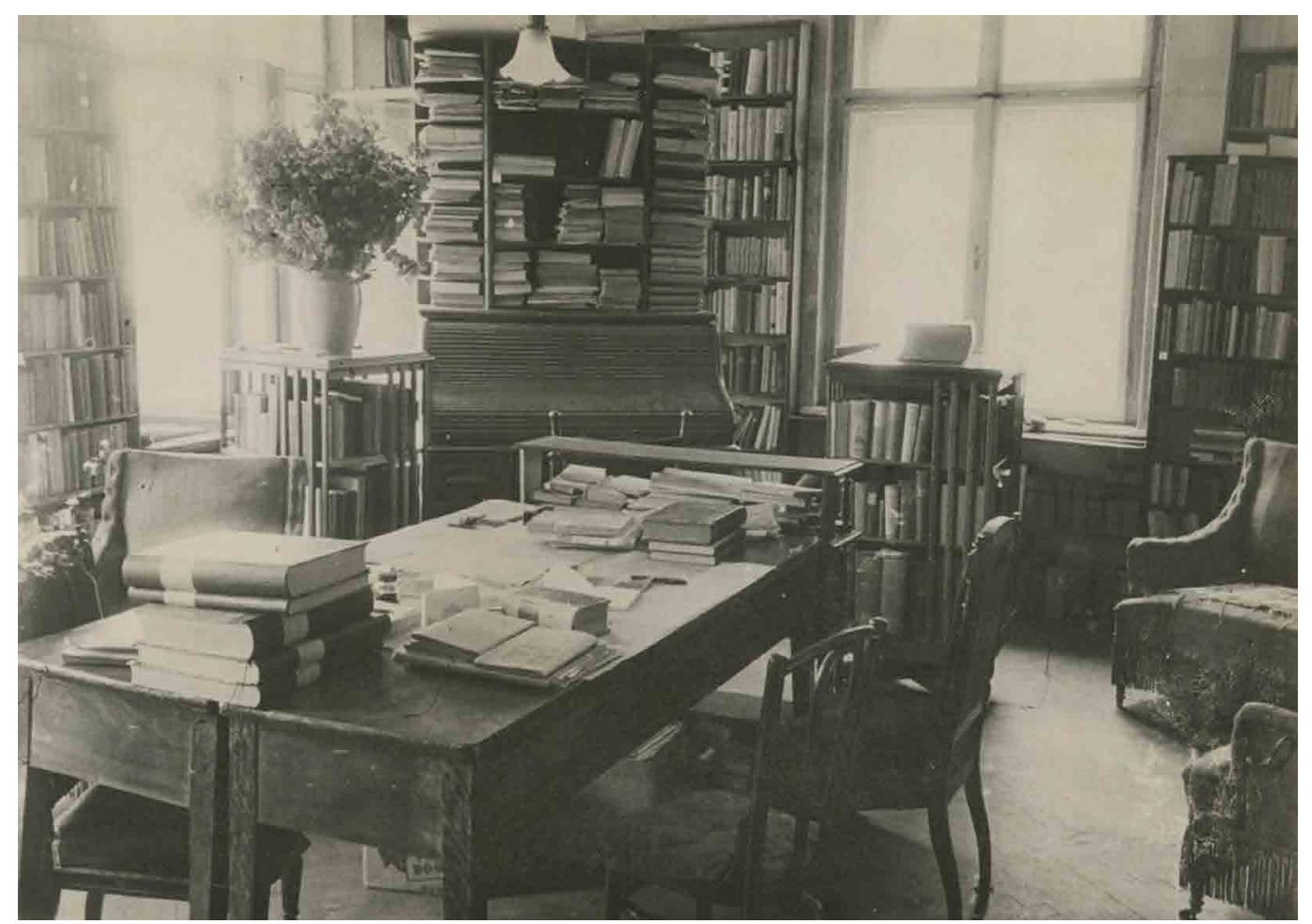

Salon w mieszkaniu Wincentego Lutosławskiego, Kraków, ul. Szwedzka 10/2, początek XX wieku (ze zbiorów Polskiej Akademii Umiejętności, http://pauart.pl/app/artwork?id=AN_KIII_155_9130; domena publiczna) 


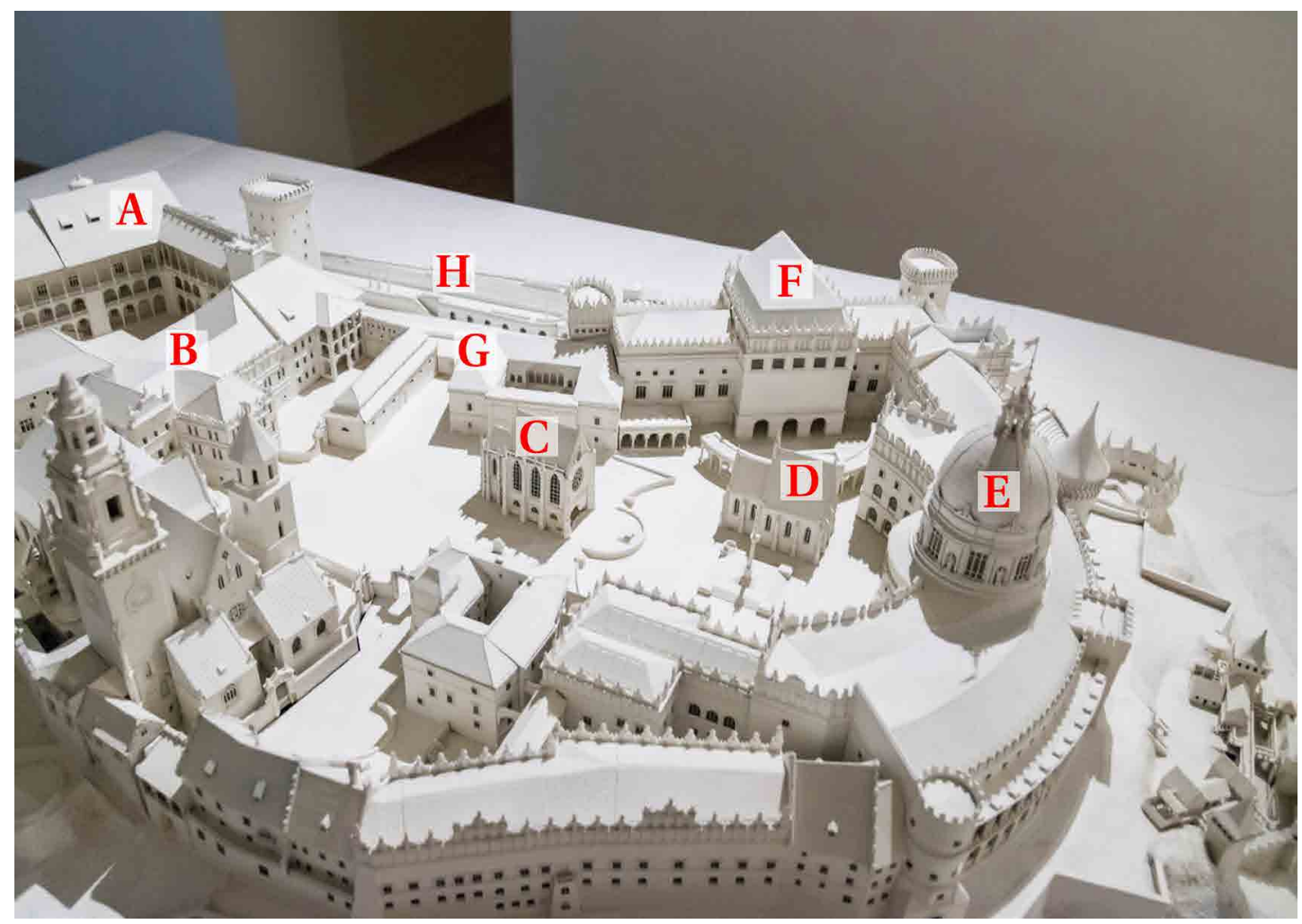

Makieta projektu przebudowy Wawelu autorstwa Stanisława Wyspiańskiego i Władysława Ekielskiego, Muzeum Wyspiańskiego, Kraków (opis ilustracji w tekście artykułu; praca własna K.M.)

Wyspiański i Ekielski zaprojektowali na Wawelu miejsce narodowego wyzwolenia Polaków i odrodzenia polskiego ducha, narodowo-katolicką świątynię i centrum władz państwowych jednocześnie. Ponieważ chcieli restytucji monarchii, renesansowy zamek królewski na Wawelu (A na zdjęciu makiety) miał odzyskać swoją pierwotną funkcję, a nie stać się muzeum ${ }^{5}$. Przy nim, jako integralna część władzy, znaleźć się miał pałac biskupi (B). W projekcie Wyspiański i Ekielski rekonstruowali także dwa wolnostojące kościoły, wcześniej zburzone (C, D).

Nowoprojektowany w miejscu austriackich koszar monumentalny budynek z potężną kopułą miał być senatem polskim (E). Ten z dachem czterospadowym - to sejm (F). Obok senatu zaprojektowano apartamenty króla, osobne wobec pałacu. Jak pisze Ekielski, do budynków rządowych przylega „Akademia Umiejętności, którą ś.p. Wyspiański nazywa Kapitolem, Walhallą" (G). Jest to instytucja poświęcona badaniu narodowej historii, prze-

5 Broszura przedstawiająca projekt Wawelu-Akropolis pisana jest przez Ekielskiego już po śmierci Wyspiańskiego. Ekielski był wyłącznie praktykiem architektury, ubiera więc ideologiczny program Wawelu w pragmatyczne, budowlane argumenty projektowe. Jego opis uderza miejscami swoją naiwnością, za którą niewątpliwie kryją się echa wcześniejszych rozmów obu projektantów. O Zamku Królewskim na Wawelu Ekielski pisze: „mamy przekonanie, że Zamek Królewski tym starożytnym królewskim zamkiem pozostać powinien i innym celom służyć nie powinien. [...] Uważamy, że niesłusznym jest zmieniać charakter i przeznaczenie budynku starożytnego: odnieść to musimy w najwyższej mierze do tak ważnego monumentu narodowego, jakim jest Zamek. Jego struktura, jego rozległe sale, czynią go na cele np. Muzeum Narodowego nieprzydatnym" (Ekielski \& Wyspiański, 1908, s. 5). 
znaczona "na doroczne uroczyste zebrania i posiedzenia komisji mających związek z przeszłością" (Ekielski \& Wyspiański, 1908, s. 9). Niedaleko stamtąd, bezpośrednio pod wzgórzem wawelskim, znaleźć się miał także Stadion Sokoła $(\mathrm{H})$, ,na którym młodzieńce po laury sięgną, bo silnym na ciele i umyśle ma być nasz naród” (Ekielski \& Wyspiański, 1908, s. 10). Stadion przylegać miał do kościoła Bernardynów pod Wawelem, ufundowanego w późnym średniowieczu przez Jana Kapistana, papieskiego inkwizytora, organizatora pogromów i wypędzeń Żydów, świętego Kościoła katolickiego.

Dla Wyspiańskiego punktem odniesienia do prac nad Wawelem była istniejąca już Walhalla - budynek położony w Bawarii, pod Ratyzboną nad Dunajem, zaprojektowany w formie greckiej, doryckiej świątyni. Zbudował go w latach 1830-1842 książę bawarski Ludwik I jako Świątynię Chwały Narodu Niemieckiego. Jest to świątynia zmarłych, wypełniona popiersiami twórców kultury niemieckiej: kompozytorów, pisarzy, poetów, polityków; natomiast starogrecki wystrój to aluzja do rzekomego pokrewieństwa germańskich Aryjczyków i starożytnych Greków - na fryzie świątyni wyobrażone jest „wyjście Germanów z Kaukazu", z Himalajów i gór Kaszmiru, z przystankiem na Peloponezie (Błoński, 1994, ss. 72-73). Kryterium doboru bohaterów panteonu było rasowo-etniczne i językowe - znalazły się w niej popiersia osób uznanych za Niemców w sensie rasowo-etnicznym, działających w sferze języka niemieckiego. Walhalla to zatem swoiste centrum niemieckiego faszyzmu, powstałe, kiedy niemieckiego nazizmu jako ideologii politycznej jeszcze nie było. Wyspiański tam był, zwiedzał. Mimo swojego wybitnie faszystowskiego charakteru Walhalla przez długie dziesięciolecia po upadku nazizmu pozostawała w świadomości niemieckiego społeczeństwa odrębna i oddzielona od faszyzmu i nazizmu. Dopiero po 2000 roku, być może dla rozrzedzenia proto-nazistowskiego charakteru tego miejsca, dodano tam kilka popiersi, m.in. Heinricha Heinego, wykluczonego wcześniej z niemieckości z powodu żydowskiego pochodzenia ${ }^{6}$, a także osób walczących z nazizmem, np. Sophie Scholl.

Dla Wyspiańskiego Wawel był polską Walhallą, bezpośrednią odpowiedniczką bawarskiej. To nie jest moja myśl, ale Jana Błońskiego, który w tekście z 1994 roku dokładnie to pokrewieństwo przeanalizował (Błoński, 1994). Szczególnie była takim miejscem wawelska katedra, wypełniona kośćmi polskich królów i bohaterów, pełna uśpionego przez dekady zaborów „ducha” narodowego. Kluczem pozwalającym odczytać intencje Wyspiańskiego jest Wyzwolenie - dramat, gdzie wiele jest pisanych zupełnie otwartym językiem wątków rasistowskich, mizoginicznych, wezwań do czystości etnicznej. Akcja dramatu rozgrywa się późnym wieczorem na pustej scenie krakowskiego Teatru Miejskiego, dzisiejszego Teatru im. Juliusza Słowackiego, gdzie pojawia się Mickiewiczowski Konrad. Dalej napotyka on serię Masek, wyrazicielek głosów różnych nurtów kultury, z którymi Konrad debatuje na przykład tak:

6 Inna rzecz, że Heine był bardzo krytyczny wobec koncepcji budowy Walhalli (Błoński, 1994, s. 71). 
Konrad: U nas jest kraj gościnny. No, tak się zmieści każdy złodziej. Złodziej tym ludziom, którzy by się urodzić mieli z czystej krwi narodu. [...] Oto przede wszystkim powinniśmy uszanować krew narodu. I nie dać jej marnować. Nie pozwolić marnować krwi narodu. [...] Nie pozwolić prostytuować naszych kobiet. [...] My nie powinniśmy pozwolić naszych kobiet obcym, tym obcym, którzy siedzą wśród nas.

Maska 12: Ależ kobiety są niezależne.

Konrad: Nie, nie są i nie będą. Bo całym ich życzeniem i dążeniem powinno być, żeby od tej myśli niezależne nie były. [...] One same są niczym. Nie mogę ścierpieć i znosić, i słuchać, że kobieta Polka przeistacza dom męża obcego i czyni zeń dom polski. Jeżeli tak czyni, to czyni podłość. Czyni podłość, która się prędzej czy później odezwie w charakterze potomstwa. [...] winniśmy przeciwdziałać i nie pozwolić marnować naszej krwi i naszych dziewcząt, tak dobrze obcym, jak swoim. Tego nie powinniśmy, a to tylko może zrobić [...] polski rząd. Bo żaden inny naszych interesów, interesów naszej krwi bronić nie będzie. Bo inne są dla nas i naszych spraw, i naszych świętości oszustami! (Wyspiański, 1970, ss. 108-111).

Wcześniej bohater mówi o konieczności „cenzury narodowej”, „która by działała tak, jak działają cenzury we wszystkich państwach wszystkich narodów”, i przeciwdziałała „kradzieży narodu”, działaniom „oszustów, którzy rujnują naród” i „złodziei, którzy okradają naród” (Wyspiański, 1970, s. 106). Niewątpliwie są to echa dyskusji, którym się Wyspiański, „siedzący zawsze cichutko", przysłuchiwał, wspólnie z trzema córkami Lutosławskiego.

Kulminacyjna scena Wyzwolenia odbywa się w lochach wawelskich, do których grupę członków narodu polskiego wprowadza Konrad:

Konrad: Pójdą, gdziekolwiek ich powiodę i będą ze mną razem, za moim walczącym Słowem, którego używać będą wszędy [...] Będzie to: KOŚCIÓt WOJUJĄCY. [...] Wejdziemy w progi gmachu, po wstopniach wysokich i staniemy przy kolumnach. A nad naszymi głowami wysoki strop sklepiony, umalowany błękitem i posiany srebrem gwiazd.

Maska 6: Kościół żywych.

Konrad: Kościół umarłych. A którykolwiek wnijdzie tam i stanie pomiędzy nami jako pomiędzy swoimi, ten wyzuty już będzie ze wstrętów życia, oczyszczony ze zapędów złych i każących ducha, i będzie bratem mnie i braci mojej. A na dzień onego wielkiego święta, które będzie świętem narodu, otworzę zawory sklepów podziemnych i zejdziemy po schodach, wiodących w lochy, ku rozległym piwnicom, kędy leżą prochy wielkich w narodzie, w kamiennych i złocistych zamknione skrzyniach.

Maska 6: Królewskie groby (Wyspiański, 1970, ss. 78-80).

Szkielety królów, kult trupów, ekshumacje. W latach trzydziestych XX w. krakowscy działacze polityczni i archeolodzy otworzyli prawie wszystkie trumny królów w wawelskich kryptach i obficie się ze szkieletami fotografowali. Faszystowski kult śmierci odbył się na żywo.

Krytycy kultury polskiej neutralizowali warstwę rasistowską i mizoginiczną dramatu. Bagatelizowali inspiracje endeckie Wyspiańskiego. Jedyną osobą, która krytycznie odtworzyła ten mechanizm, był Grotowski. W 1963 roku przeniósł on na scenę inny dramat wawelski Wyspiańskiego, Akropolis, pokazując Wawel jako przestrzeń obozu zagłady Au-

7 Trumny królów otwierano wielokrotnie w ciągu lat trzydziestych. Największą taką operację podjęto podczas konserwacji i prac archeologicznych w krypcie św. Leonarda w katedrze wawelskiej, prowadzonych w latach 1937-1938 pod kierunkiem Adolfa Szyszko-Bohusza (Płuska, 2009). 


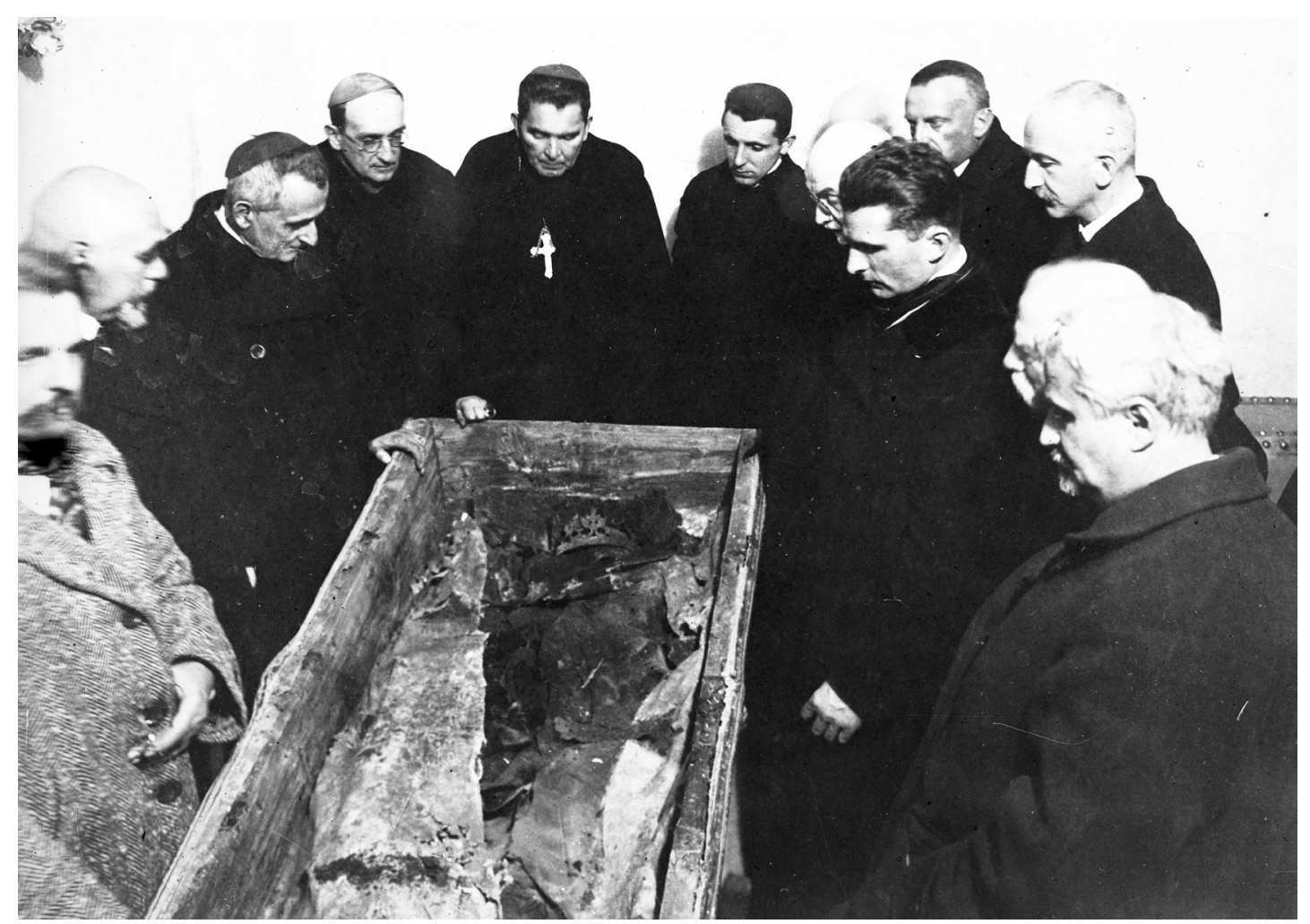

Otwarcie trumny Zygmunta II Augusta w 1930 roku. Przy trumnie stoją (od lewej): profesor UJ Tadeusz Estreicher, wiceprezydent Krakowa Witold Ostrowski, biskup krakowski Adam Sapieha, biskup łucki i żytomierski Michał Godlewski, biskup pomocniczy krakowski Stanisław Rospond, trzy nieznane osoby, profesor UJ Tadeusz Kruszyński (ksiądz), prof. UJ Kazimierz Władysław Kumaniecki, nieznana osoba, dyrektor Muzeum Narodowego w Krakowie Feliks Kopera (ze zbiorów Narodowego Archiwum Cyfrowego, https://audiovis.nac.gov.pl/obraz/87554:1/; domena publiczna)

schwitz ${ }^{8}$. Tym samym Grotowski ujawnił coś, co ma być ukryte i jawić się jako neutralne. Tym czymś są rasistowskie, mizoginiczne i ksenofobiczne treści faszyzmu, które pozostają nie tylko normatywne i niekontrowersyjne, ale przede wszystkim bardzo polskiemu państwu potrzebne i użyteczne. Te treści pozostają aktywne do dzisiaj też dlatego, że dla elitarnych komentatorów kultury polskiej, krytyków teatralnych, badaczy architektury, faszystowskie dzieło kultury staje się bezproblemowe, jeśli jest dziełem kultury polskiej. Tak jak niemiecka Walhalla jest dziś po prostu ciekawym dziewiętnastowiecznym zabytkiem z interesującymi rzeźbami w środku. Faszyzm jest integralną częścią Polski i Europy tak długo, jak długo jest duchowo głęboki, elegancki, elitarny i nie przeklina.

Na przykładzie Lutosławskiego i Wyspiańskiego dobrze widać, w jaki sposób ideologia faszystowska dostaje się do głównego obiegu kultury. Dzieje się to w centrum Krakowa, w salonie polskiego filozofa o światowej sławie. Faszyzacja jest zatem tylko odsunięciem teatralnej kurtyny. Za nią czeka już to wszystko, co od dawna było

8 Mowa o spektaklu Jerzego Grotowskiego i Józefa Szajny Akropolis, wystawionym w Teatrze - Laboratorium 13 Rzędów w Opolu w 1962 roku. 
eliminacyjnym, morderczym elementem europejskiej kultury. Dokonywany przez faszystę gest odsłonięcia jest obsceniczny, ale to, co znajduje się za kurtyną, nie zostało tam ustawione przed chwilą, ani tym bardziej przez tych, którzy dziś określaliby się mianem faszystów. Zestaw za kurtyną można wyjaskrawić, ubrać w mundur i specjalne gesty. Ale zestaw ten był już w naszych domach, nim podeszli pod ich progi faszyści w mundurach i opaskach z falangą.

K.S.: Śmierć jest w centrum kultury faszystowskiej. Śmierć obcych, ale także śmierć własna na rzecz narodu lub państwa. Dlaczego nikt nie zakwestionował kultu śmierci w Wyzwoleniu?

K.M.: W dramacie ten kult widać gołym okiem. Mimo to Konstanty Puzyna i Michał Głowiński bronili w swoich recenzjach Wyspiańskiego tłumacząc, że w Wyzwoleniu nie ma nic endeckiego, to były tylko luźne inspiracje. Odpierając zawłaszczenie Wyspiańskiego przez nacjonalistów, Michał Głowiński pisze o krytycznym publicyście:

nie zauważa [on] jakby, że do sprawy tej [obrony krwi narodu] w dalszym toku dramatu już się nie powraca, nie budzi w nim więc refleksji ta właściwość Wyzwolenia, [...] którą musiał przecież spostrzec: wypowiada się $w$ nim wiele różnych opinii na różne tematy i nie można uznać wszystkich za obowiązujące czy też takie, które przekazują serio poglądy poety (Głowiński, 1990, s. 54).

\section{A Puzyna pisat:}

Pamiętajmy jednak, że co innego znaczyły te hasła [Siły i Mocy] w sytuacji galicyjskiego roku 1900: były po prostu żądaniem programu politycznego, przerwania chocholego tańca. Żądał tego nawet Daszyński - ogólniki Wyspiańskiego przyjmowali wszyscy za swoje. „Rasistowskich" pomysłów Konrada w scenie z Maskami [...] nie można również przypisywać bezpośrednio ideologii autora (Puzyna, 1957-1958, ss. 10-11).

Mamy tu więc faszyzm bez faszystów.

A.Z.: Zaciekawił mnie wątek ezoteryczny w tej historii i związana z nim obsesja czystości. Czystość ducha koresponduje z czystością krwi i „rasy”. W tym sensie przyswojona przez Europę dalekowschodnia ezoteryka nie odbiega daleko od chrześcijaństwa. Mamy tu także koncepcję brudu, którego trzeba się pozbyć, najlepiej projektując go na innych, a następnie tych innych zabijając lub wypędzając.

K.M.: Stowarzyszenie Eleusis miało cztery nakazy czystości: zakaz picia alkoholu, palenia papierosów, hazardu i seksu uprawianego dla przyjemności. Lutosławski pisał: „Koła Eleusis to są ogniska nowego zakonu religijnego, przez wstrzemięźliwość ćwiczącego swych uczestników w ofiarności, przez czystość radykalnie zmieniającego stosunki płci, a co za tym idzie wpływającego na podniesienie rasy" (Lutosławski, 1903, s. 289). 


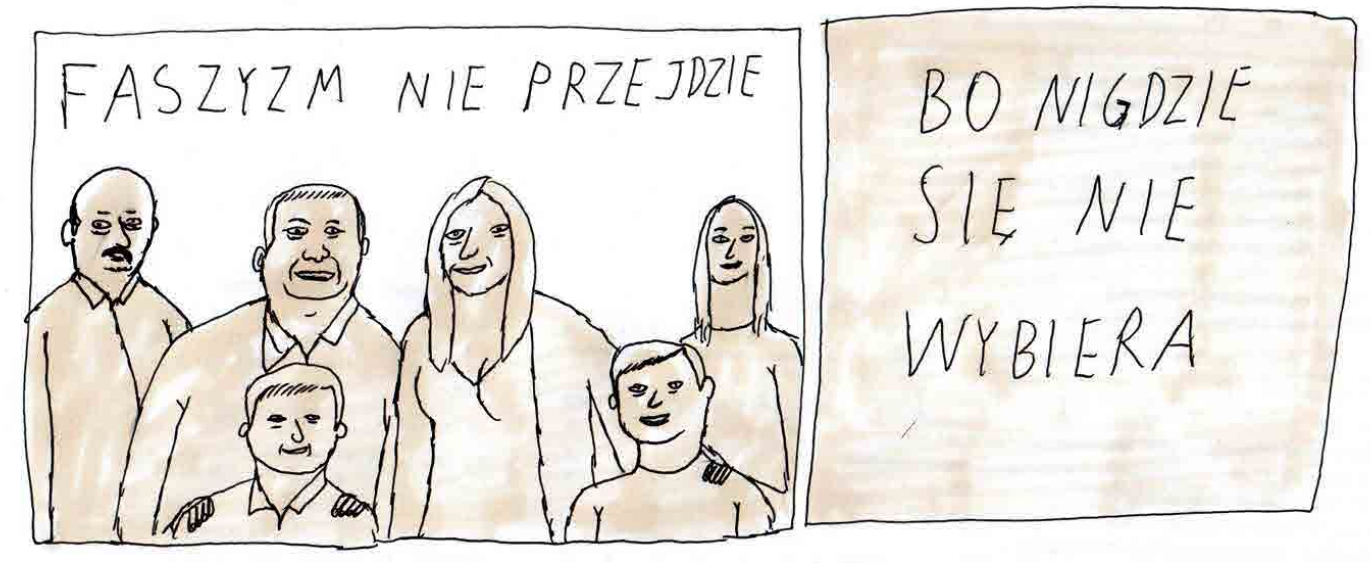

Ilustracja: Janek Koza, „Polityka” z 24 stycznia 2020 roku (@Janek Koza)

Xawery Stańczyk: Zgadzam się z Konradem, że w Polsce trudno mówić o faszyzacji, ponieważ faszyzm tu jest i był. On jest elementem stałym, a nie czymś, co zachodzi. Raz się chowa, raz ujawnia, ale nie znika. W wymiarze lokalnym zabrakło defaszyzacji, po której mogłaby nastąpić ponowna faszyzacja. Doskonale zilustrował to Janek Koza rysunkiem „Faszyzm nie przejdzie, bo nigdzie się nie wybiera”: hasło znane z demonstracji antyfaszystowskich okazuje się tutaj, przewrotnie, faszystowską deklaracją bycia u siebie.

W wątku subkulturowym, o którym wspomniał Marcin, interesuje mnie, na ile faszyzm przenika do przestrzeni autonomicznych, które próbują być antyfaszystowskie. Wydaje mi się, że tu łatwiej zaobserwować faszyzację jako proces, np. na przykładach odrzucenia portretów Che Guevary i popularyzacji antykomunistycznego znaku trzech strzał, o czym Marcin też wspominał. W ten sposób Polska dorobiła się m.in. patriotycznego antyfaszyzmu, o czym pisałem w kontekście Slamu patriotycznego połączonego z benefitem na "Antifę” - pod tym mianem ukrywał się Studencki Komitet Antyfaszystowski, obok Stołu Powszechnego i Autonomicznej Przestrzeni Edukacyjnej, jeden ze współorganizatorów wydarzenia (Stańczyk, 2019). Opis wydarzenia przedstawiał patriotyzm jako wartość pozytywną, a przynajmniej możliwą do pozytywnego przedefiniowania - przedmiotem slamu miała być wspólnota rozumiana w sposób otwarty i niewykluczający. Patriotyzm deklarowany przez organizatorów powiązany został ze wspólnymi nadziejami i walkami, troską o przyrodę i zamiłowaniem do lokalności, w przeciwieństwie do patriotyzmu nacjonalistycznego i faszyzującego, który byłby czysto agresywny i wykluczający. Miłość do ojczyzny jako otwartej, inkluzywnej i ekologicznej wspólnoty miałaby stać się w tej wizji podstawą - tyleż ideową, co finansową - postawy antyfaszystowskiej. Tymczasem fantazja o możliwości istnienia takiej nieskazitelnej moralnie 
wspólnoty toczącej solidarną walkę z wrażymi siłami sama w sobie należy do rezerwuaru wyobraźni faszystowskiej.

Jeszcze większe pomieszanie antyfaszyzmu z faszyzmem zachodzi w przypadku demonstracji organizowanych co roku 11 listopada przez Koalicję Antyfaszystowską. Od 2018 roku Koalicja Antyfaszystowska wraz z szeregiem innych podmiotów (w tym skłot Syrena, Studencki Komitet Antyfaszystowski, Antyfaszystowska Warszawa oraz Porozumienie Kobiet 8 Marca) organizuje tego dnia „taneczny pochód”, którego trasa przebiega zwykle zaledwie kilka czy kilkanaście przecznic od Marszu Niepodległości, czyli największego faszystowskiego wydarzenia w Europie, które w ostatnich latach gromadziło dziesiątki tysięcy uczestników z całego kontynentu. Znane z wcześniejszych lat blokady i kontrdemonstracje wobec faszystowskiego przemarszu zastąpione zostały swoistą rywalizacją na bardziej prawomyślny patriotyzm. W wydaniu Koalicji Antyfaszystowskiej miałby on posiadać „pozytywny” i „kolorowy” charakter, co znalazło wyraz m.in. w powracającym w kolejnych latach haśle „Za Wolność Waszą i Naszą!” czy posługiwaniu się wyrażeniami znanymi z nacjonalistycznego dyskursu: „ojczyzną” będzie tu nie tyle kraj, co „Ziemia i Życie”, a „niepodległość” stanie się postulatem grup marginalizowanych społecznie (Koalicja Antyfaszystowska, 2019). Być może celem tych gier językowych jest przyciągnięcie do idei antyfaszyzmu liberalnej klasy średniej - istotnie w ostatnich latach na deklaratywnie antyfaszystowskich i antyrasistowskich wydarzeniach pojawia się więcej osób spoza klucza subkulturowo-aktywistycznego. Jednakże ta koncesja, oznaczająca de facto rezygnację z własnego języka opisywania rzeczywistości społecznej, czyni z rachitycznego „ruchu” antyfaszystowskiego (w cudzysłowie, ponieważ środowisko jest tak niewielkie, rozproszone, anomiczne i niejednorodne, że nie sposób mówić o nim jako o ruchu w kategoriach socjologicznych) zakładnika kultury dominującej, która, jak zauważyła Katrin, posługuje się kodem antysemickim, a właściwie jest kulturą antysemicką.

Tym, co w tego rodzaju sytuacjach łączy faszystów i antyfaszystów jest nie tylko deklaracja (różnie definiowanego) patriotyzmu i elementy zaczerpnięte z narodowej historii (insurekcja kościuszkowska, powstanie warszawskie, Armia Krajowa), lecz także silny antykomunizm, o którego fundamentalnej roli dla zdefiniowania faszyzmu także już mówiliśmy. To właśnie antykomunizm obok częściowej rehabilitacji nacjonalistycznego języka i narodowej mitologii sprawia, że „ruch” antyfaszystowski w Polsce nie jest w stanie zaoferować realnej alternatywy wobec wszechobecnego faszyzmu - podmywany przez fale faszyzacji, czyni kolejne koncesje na ich rzecz, a w rezultacie traci samodzielność polityczną, choć zachowuje dystynkcję na poziomie stylu, dystynkcję nierzadko klasową wobec „źle ubranych” sympatyków Ruchu Narodowego i Konfederacji, zjeżdżających z prowincjonalnych ośrodków na Marsz Niepodległości. „Od czasu międzywojennego faszyzmu pojęcie «faszyzm» pozostaje w modzie. Która grupa polityczna nie oskarżała swoich przeciwników o używanie «faszystowskich metod»? Lewica nigdy nie przestaje demaskować odradzającego się faszyzmu, prawica nie wystrzega się tego ter- 
minu, nazywając Francuską Partię Komunistyczną «partią faszystowską»" - pisał Jean Barrot, którego zdaniem liberalna opinia publiczna tworzy iluzję faszyzmu, żeby potępić wybrane państwo lub jego kierownictwo. Barrot uważał, że po 1945 roku faszyzm jako forma organizacji państwa i ruch polityczny był już właściwie nieobecny (mimo pewnych podobieństw np. w Grecji lub Chile), krytyka „faszyzmu” w poszczególnych państwach przesłania krytykę państwa jako takiego. „Lewica próbuje uwierzytelnić swój ekstremizm, podnosząc wrzawę o faszyzm, pomijając tym samym krytykę państwa” (Barrot, 2010). Niezależnie od historycznej trafności tych uwag, w odniesieniu do współczesnej Polski należałoby to zdanie przeformułować: lewica próbuje uwierzytelnić swój styl życia, podnosząc wrzawę o faszyzm, pomijając przy tym krytykę wzorów kultury dominującej i elit symbolicznych.

W kontekście przestrzeni potrzebę przeniesienia uwagi z ugrupowań skrajnej prawicy na kulturowy i polityczny mainstream dostrzec można przez pryzmat krajobrazu i topografii. Przestrzenne ujawnianie się faszyzmu jest ściśle powiązane z polityką przestrzenną na poziomie miejskim, która stanowi wypadkową neoliberalnej i neokonserwatywnej ideologii oraz interesów lokalnych elit, a także z polityką antykomunistyczną na poziomie krajowym. Działania związane z dekomunizacją przestrzeni publicznej przeprowadza w Polsce aparat władzy. Tu nie ma kontrowersji ani zaskoczenia. Od czasu otwarcia Muzeum Powstania Warszawskiego (dalej: MPW) w 2004 roku jest to faszyzm jawny, a wręcz puszący się jak paw: MPW stanowi gwarancję osadzenia mitu powstania w centrum narodowego imaginarium, co skutecznie ucina jakiekolwiek próby dyskusji czy podważania tego mitu. Sytuacja staje się mniej oczywista, gdy faszyzację przestrzeni przeprowadzają obywatele światli i liberalni. Dzieje się tak za sprawą estetyzacji przestrzeni zgodnie z „nowoczesnym” gustem nowej klasy średniej, która wywiera coraz większy wpływ na politykę przestrzenną. W ciągu ostatnich lat z przestrzeni publicznych usuwane było to, co w oczach tej klasy jawiło się jako obciach i zacofanie, np. bazary i stragany, toalety publiczne czy zadrzewione skwery na głównych placach i rynkach miast. Obecnie ten trend słabnie w dużych miastach, gdzie ekologiczny styl życia i zakupy na lokalnych targach stały się elementem stylu życia nowego mieszczaństwa, ale już w średniej wielkości miastach skwery wciąż zastępowane są parkingami, co bardziej łączyłbym znów z grą w dystynkcję - średnio- i małomiastowa inteligencja i klasa średnia wprowadzają u siebie to, co podpatrzyły jako trendy w metropoliach, niekoniecznie ze względu na realny interes, np. brak miejsc parkingowych. Przy okazji z odnowionych reprezentacyjnych przestrzeni publicznych usuwane są osoby biedne, „nieodpowiednio” zachowujące się mniejszości - np. Romowie trudniący się graniem muzyki czy wróżbiarstwem - co niejednokrotnie wiąże się z częściową komercjalizacją takich przestrzeni oraz wzrostem kontroli (okoliczne sklepy i restauracje zatrudniają ochroniarzy, którzy przepędzają osoby niepasujące do wizerunku miejsca, wprowadzany jest monitoring itd.). Ponadto rewitalizowane i estetyzowane przestrzenie często pozostają trudno dostępne dla osób z niepełnosprawnością czy dla kobiet (chociażby matek z wózkami). 
Zmiany te mają zatem nie tylko wymiar klasowy - dopasowania przestrzeni do kryteriów określonego gustu - lecz także płciowy i narodowy, a prowadzą do ustanowienia homogenicznej przestrzeni miejskiej, w której często jedynie wytyczne konserwatorskie stanowią zabezpieczenie lokalnej swoistości przed sojuszem małego i dużego biznesu oraz narodowego ujednolicenia.

Szczególnie interesujący pod tym względem jest styk praktyk estetyzacji i dekomunizacji, w ramach której z przestrzeni publicznych usuwa się także to, co wiąże się z poprzednim ustrojem, a zwłaszcza formy upamiętniania komunistycznych bohaterów i wydarzeń. W ustawie z 1 kwietnia 2016 roku o zakazie propagowania komunizmu lub innego ustroju totalitarnego przez nazwy budowli, obiektów i urządzeń użyteczności publicznej rok później wprowadzono poprawki zobowiązujące samorządy do rozbiórki pomników upamiętniających „osoby, organizacje, wydarzenia lub daty symbolizujące komunizm lub inny ustrój totalitarny" albo propagujących taki ustrój w inny sposób (Ustawa z 1 kwietnia 2016 r., Dz.U. 2016, poz. 744). Liczbę takich pomników szacowano na ok. 500, a wejście w życie poprawionej ustawy pociągnęło za sobą wyburzenia pomników w całej Polsce. Niemniej niszczenie komunistycznych pomników zaczęło się już wraz z początkiem III RP, a zintensyfikowało się w ostatnich latach bez ścisłego związku z ustawą. Za przykład może posłużyć likwidacja komunistycznych pomników w Warszawie rządzonej przez konserwatywnych liberałów z Platformy Obywatelskiej. Jeszcze w 2011 roku zdemontowano Pomnik Braterstwa Broni na pl. Wileńskim, co wówczas uzasadniano budową drugiej linii metra. Jednak już w lutym 2015 roku Rada Warszawy postanowiła, że pomnik nie wróci, mimo jego dużej wartości historycznej - był to pierwszy monument wzniesiony w Warszawie po wojnie - i wbrew woli większości mieszkańców i mieszkanek, którzy oczekiwali powrotu pomnika (Szpala, 2013). Ostatecznie obiekt przekazano do Muzeum Historii Polski (dalej: MPH), które ma włączyć je do przyszłej ekspozycji na temat PRL. Można przypuszczać, że będzie to wystawa zjadliwie antykomunistyczna.

Do zbiorów MHP miały trafić też szczątki pomnika generała Zygmunta Berlinga. Choć pomnik został obalony w sierpniu 2019 roku przez „nieznanych sprawców” - nieznanych w cudzysłowie, ponieważ informacją o zniszczeniu jako pierwszy pochwalił się były poseł Konfederacji Polski Niepodległej Adam Słomka - to władze dzielnicy Praga-Południe już wcześniej, w maju 2019 roku, podjęły decyzję o demontażu obiektu i przekazaniu go MHP (widać tu jak na dłoni swoisty wyścig między prawicą skrajną a umiarkowaną). Z powodu obaw, że rozbiórka pomnika może zostać wymuszona wskutek ustawy dekomunizacyjnej, miasto zawczasu postanowiło się go pozbyć i nie podjęło próby jego przywrócenia, kiedy został zniszczony przez grupę antykomunistycznych aktywistów (kn, 2019).

Również bez odgórnego przymusu wyburzono w październiku 2018 roku Pomnik Wdzięczności Żołnierzom Armii Radzieckiej w parku Skaryszewskim. Za rozbiórkę odpowiadał tym razem Zarząd Zieleni m.st. Warszawy, którego ówczesny dyrektor, Marek Pi- 
wowarski, wyjaśniał: „Ta rozbiórka wynika z ustawy dekomunizacyjnej, ale też z prowadzonej w tej chwili przez nas rewitalizacji parku Skaryszewskiego. Dostaliśmy na to zgodę IPN i wojewódzkiego konserwatora zabytków" (Urzykowski, 2018). Z wypowiedzi tej wynika, że nie było nacisku z góry na usunięcie pomnika. To Zarząd Zieleni wyszedt z inicjatywą i wystąpił po odpowiednie zgody do IPN i konserwatora zabytków. Działanie prowadzono w ramach rewitalizacji parku - jednym z argumentów miało być przywrócenie pierwotnej osi widokowej centralnej alei parku, w której znajdował się obiekt. A więc względy estetyczne pozwoliły Zarządowi Zieleni, którego zadania koncentrują się przecież na dbaniu o roślinność w mieście, na prowadzenie antykomunistycznej polityki historycznej, pomimo protestów Rosji oraz mieszkańców i mieszkanek Warszawy, w tym stołecznego Sojuszu Lewicy Demokratycznej. „Dla mieszkańców Pragi-Południe park Skaryszewski jest przestrzenią do wypoczynku i rekreacji. Oprócz bujnej przyrody, kryje się tu wiele ciekawostek historycznych. Przywracamy blask temu miejscu, aby dzieci i dorośli mogli w pełni korzystać z uroków zielonego zakątka dzielnicy" - deklarował wiceprezydent Warszawy Michał Olszewski (Klimczak, 2018). Zarówno dyrektor Piwowarski, jak i prezydent Olszewski to osoby cenione przez liberalnie nastawioną opinię publiczną; gdy w marcu 2019 roku ratusz ogłosił dymisję Piwowarskiego, część środowisk tzw. ruchów miejskich przyjęła ją z rozżaleniem, pojawiły się nawet listy protestacyjne (lulu, 2019). Elementy wyburzonego Pomnika Wdzięczności trafiły do IPN, który ma je umieścić w skansenie Muzeum Zimnej Wojny w Podborsku na Pomorzu Zachodnim, zostaną więc wykorzystane propagandowo. W ten sposób liberalne ugrupowania, zainteresowane zielenią i estetyką przestrzeni publicznych, realizują politykę antykomunistycznej prawicy. Ta polityka rugowania wszystkiego, co może kojarzyć się z komunizmem, z przestrzeni publicznej, otwiera w tej przestrzeni na oścież drzwi faszyzmowi, który nie znajduje w niej już żadnego przeciwnika - może poza globalnym kapitałem unikającym kontrowersyjnych asocjacji - jest więc bezpośrednio odpowiedzialna za faszyzację.

Drugim po Warszawie przykładem jest Trzcianka, miasteczko na północy Wielkopolski. W ramach rewitalizacji Placu Pocztowego, wcześniej Armii Czerwonej, we wrześniu 2017 roku wyburzono tam Mauzoleum Armii Czerwonej bez dokładnej weryfikacji, czy nie znajdują się pod nim szczątki 56 żołnierzy, którzy zostali tam pochowani w 1945 roku. Podstawą wyburzenia mauzoleum była decyzja wojewody wielkopolskiego Zbigniewa Hoffmanna o wykreśleniu obiektu z rejestru cmentarzy wojskowych na podstawie badań elektromagnetycznych i georadarowych, które wprawdzie nie wykryły szczątków ludzkich, ale nie wykluczyły, że ich tam nie ma - nie ma konsensusu co do tego, czy w wyniku ekshumacji z 1953 roku szczątki żołnierzy przeniesiono na cmentarz w Wałczu, czy zostawiono na Placu Pocztowym (Biespałowa, 2017; Swiridow, 2019). W następstwie tej decyzji uznano, że mauzoleum jest jedynie symbolicznym upamiętnieniem, co oznaczało, że jego losy znalazły się całkowicie w rękach lokalnego samorządu. Ówczesny burmistrz Trzcianki, Krzysztof Czarnecki, postanowił wyburzyć obiekt 
w ramach rewitalizacji, aby postawić tam Centrum Integracji Społecznej (dalej: CIS); sam plan rewitalizacji został przyjęty w 2016 roku, a więc jeszcze przed decyzją wojewody. Po wyborach prace budowlane na miejscu po wyburzonym mauzoleum kontynuował nowy burmistrz Krzysztof Jaworski, w przeciwieństwie do swojego poprzednika już niezwiązany z PiS - również on nie zgodził się na przeprowadzenie ekshumacji. W 2020 roku budowa CIS została zakończona.

Przeciwko wyburzeniu mauzoleum i budowaniu na grobach protestowały Ministerstwo Spraw Zagranicznych i Ambasada Federacji Rosyjskiej, które powoływały się na polsko-rosyjski traktat z 1992 roku regulujący m.in. kwestię cmentarzy i miejsc pamięci. Pomimo wybuchu skandalu dyplomatycznego działania burmistrza Trzcianki poparły m.in. Ministerstwo Kultury i Dziedzictwa Narodowego oraz IPN. W 2019 roku do sprawy podejmowanej przed polskimi sądami przez stowarzyszenie Kursk włączyły się rodziny żołnierzy pochowanych w Trzciance, które domagały się wstrzymania prac. Wobec odmowy wszczęcia postępowania przez prokuraturę, 4 września 2020 roku sprawa trafiła do Europejskiego Trybunału Praw Człowieka.

Zgodnie z nazwą projektu „Zagospodarowanie Placu Pocztowego wraz z utworzeniem Centrum Integracji Społecznej oraz zagospodarowanie terenu Targowiska Miejskiego wraz z terenami przyległymi" finansowanego w ramach programu Wielkopolskiego Regionalnego Programu Operacyjnego na lata 2014-2020 z Europejskiego Funduszu Rozwoju Regionalnego (kwota dotacji: ponad $20 \mathrm{mln}$ zł) „[i]deą powstania CIS jest stymulowanie rozwoju lokalnej społeczności poprzez wspieranie oddolnych inicjatyw i projektów, zmierzających do aktywizacji i integracji różnych grup społ., w tym szczególnie osób zagrożonych wykluczeniem. W tym celu obiekt zostanie udostępniony podmiotom ekonomii społecznej oraz grupom nieformalnym". Ponadto modernizacja Placu Pocztowego i Targowiska Miejskiego miała stworzyć „urbanistycznie spójną, funkcjonalną i otwartą przestrzeń miejską" (Mapa dotacji, b.d.). Znaczną część CIS zajęła Biblioteka Publiczna i Centrum Kultury, zaś obok nowego budynku stanął pomnik sarenki (Pieczyńska-Chamczyk, 2020). Do budynku CIS prowadzą schody zniszczonego mauzoleum, które jako jedyne przetrwały wyburzanie. Za jednym zamachem pozbyto się zatem upamiętnienia komunizmu i zrealizowano gentryfikację centrum miasta. A wszystko to pod hasłami społeczeństwa obywatelskiego, rewitalizacji i ekonomii społecznej. Pomnik sarenki poświadcza czystość intencji i aideologiczny charakter całego przedsięwzięcia, ponieważ w Polsce komunizm uważany jest za ideologię, podczas gdy antykomunizm za przejaw zdrowego rozsądku.

I wreszcie przykład Starachowic. Miasta postindustrialnego, bez jednego centrum i spójnej przestrzeni miejskiej, powstałego jako konglomerat osiedli, kolonii robotniczych i urzędniczych oraz miasteczka Wierzbnik, które przed wojną było lokalnym sztetlem obsługującym handlowo okoliczne wsie. Osiedla powstawały dla pracowników położonej nad rzeką Kamienną huty, w pobliżu linii kolejowej, a także robotników z kopalni rudy i zakładów mechanicznych. Były rozrzucone w różnych miejscach i niepowią- 
zane ze sobą. Po wojnie na tzw. Skałkach, czyli odsłonięciu geologicznym (wysokich kamiennych blokach), zbudowano socrealistyczne, górnicze osiedle Majówka. Dziś straciło ono oryginalny układ, bo dogęszczono je nowymi blokami, a pierwotne budynki obłożono styropianem i pomalowano na pastelowe kolory. Na skraju tego terenu w czasie wojny był obóz pracy. Więziono w nim Żydów. Stosunkowo wielu z nich ocalało, bo byli potrzebni do pracy. Powstała inicjatywa społeczna upamiętnienia tego miejsca, w ramach której postawiono tabliczkę, ale po jakimś czasie tabliczka w tajemniczych okolicznościach zniknęła. Z kolei kiedy w 2014 roku rewitalizowano rynek wierzbnicki, padł filosemicki pomysł, żeby postawić tam rzeźbę kotów. Ta idea wynikała z utrwalonych we wspomnieniach starachowickich Żydów wzmianek o kotach wygrzewających się na rynku przy studniach. W ten sposób chciano przypomnieć, że Wierzbnik był miasteczkiem żydowskim, a jednocześnie urozmaicić przestrzeń rewitalizowaną według typowego w tych latach wzoru: kamienne płyty, rachityczna zieleń i miejsca dla samochodów wokót. Pomyst był tym bardziej sensowny, że na zrewitalizowanym rynku odsłonięto tablicę poświęconą zamordowanym i prześladowanym Żydom z Wierzbnika i Starachowic. Wybrano w końcu jednak inny projekt: odciśnięte w chodniku wielkie Łapy dinozaura - Świętokrzyskie jest regionem znanym z tajemniczych tropów, którymi okazały się ślady dinozaurów. To pokazuje, jak dyskurs turystyczno-krajoznawczy odsuwa nawet banalne i zawoalowane pomysły, które nawiązują do przeszłości żydowskiej. W Polsce łatwiej upamiętnić dinozaury.

Wszystkie te przypadki ilustrują faszyzację rozumianą jako proces raczej odsłaniania elementów faszyzmu już zadomowionych w kulturze niż budowania go od podstaw. A także to, jak ten proces jest wspierany przez znacznie szersze spektrum polityczne niż skrajna prawica. Dlatego zgadzam się z Konradem, że podmiot faszyzacji, o który pytał Marcin, jest elitarny. Przejawy faszyzmu widzimy na poziomie innych klas i warstw dlatego, że te klasy i warstwy mniej lub bardziej udatnie przejmują elementy kultury prawomocnej i kanonu kulturowego. Nasiąkamy nim wszyscy i wszyscy zgodnie z nim działamy. Przykładem niech będzie organizacja Ordo luris, która tworzona jest przez przedstawicieli elit politycznych i prawniczych i do elit kieruje swoje główne działania, jednocześnie z góry zastraszając szersze grupy społeczne. Polityka miejska i przestrzenna realizowana jest właśnie $w$ imię kultury: żeby był porządek, żeby było nowocześnie i estetycznie, żeby było jak na Zachodzie. To jest perspektywa lokalnych elit, które rządzą w miastach takich jak Trzcianka i kształtują przestrzeń, architekturę, krajobraz pod kątem oczekiwań i wyobrażeń własnych środowisk, tzw. społeczeństwa obywatelskiego.

A.Z.: Kiedy rozmawiamy, polskie miasta i miasteczka są szczelnie pokryte plakatami propagującymi zmuszanie kobiet do rodzenia bez względu na ich wolę, na stopień uszkodzenia płodu, na to, czy ciąża jest efektem gwałtu. Te plakaty są dosłownie wszędzie: na małych, średnich, dużych i wielkich nośnikach reklamowych, na domach, trawnikach, autostradach, ogródkach działkowych. Równie szokująca jak ich ilość jest ich treść: pragnienie całkowitego podporządkowania życia kobiet polityce pronatalistycz- 
nej, potraktowanie kobiet jako inkubatorów spełniających wolę mężczyzn, którzy z kolei reprezentują wolę narodu. Pronatalizm tego typu był stałym elementem ideologii faszystowskiej. Za plakaty i wynajem powierzchni reklamowej płaci prywatny inwestor Mateusz Kłosek, właściciel firmy Eko-Okna, jeden z najbogatszych ludzi w Polsce (Cembrowska, 2021). Widoczność tej propagandy była szczególnie dobra ze względu na okres pandemii COVID-19. Wielu reklamodawców wycofało się z przestrzeni publicznej na czas lockdownów. Różnorodność przedstawień była więc mocno ograniczona. W Poznaniu wszędobylskie plakaty mówiącego płodu przetykały jedynie: reklama rajstop, która przedstawia martwą kobietę, reklama sieci sklepów oparta na przedwojennym antysemickim haśle „Kupuj u swoich”, reklama stowarzyszenia Odra-Niemen „RodacyBohaterom.pl", na której stary, siwy mężczyzna w wojskowym mundurze całuje w czoło młodą dziewczynę o długich blond-włosach i ściska jej głowę w dłoniach, oraz plakaty przypominające o polskich powstaniach. I jeszcze reklama ankiety Instytutu Spraw Obywatelskich „akim jesteś Polakiem?” Nawiasem mówiąc, w Poznaniu widziałam wersję tego plakatu skierowaną do kobiet. „ "Jaką Polką jesteś?» Wejdź na: «jakim Polakiem jesteś»”. To dosyć dobrze obrazuje, czym są żeńskie końcówki. Jeśli nie idzie za nimi realna zmiana społecznie wytwarzanych podmiotów, stają się one wydmuszką, sztafażem.

Na wszystkich tych plakatach dominowały narodowe barwy i symbole - orzek, flaga, biało-czerwone opaski, mundur wojska polskiego. Plakaty z płodami były także w tonacji biało-czerwonej, gdzie czerwień symbolizowała krew. Tutaj krew przelana dla ojczyzny - topos faszystowski - przybrała postać kobiecych wnętrzności oraz krwi, jaką kobiety tracą podczas porodu. Swoistą, choć zapewne nieplanowaną pointą dla krwi na płodach była krew na reklamie rajstop, wypływająca z podciętej żyły martwej już kobiety.

Opisuję tak szczegółowo krajobraz reklamowy polskiego miasta, ponieważ myślę, że odzwierciedla on zarówno stopień polskiego nacjonalizmu, jego bezalternatywność, jak i towarzyszące mu wzory kulturowe, na przykład przemoc wobec kobiet, a dokładnie normalizację martwego lub zmasakrowanego kobiecego ciała. W marcu 2021 roku trudno było zobaczyć cokolwiek innego na polskich ulicach. Przestrzeń publiczna osaczała jedynie słuszną ideologią.

Xawery Stańczyk: To tylko pokazuje, czym jest ta przestrzeń. Jeśli zabierzesz z niej kampanie reklamowe międzynarodowych korporacji, zostaje wyłącznie nacjonalizm, antykomunizm i patriarchat. To przestrzeń nieprzyjazna i normatywna. Dodałbym do tego wszechobecność krzyży, kapliczek i kościołów. Dużo się ostatnio mówi o zanieczyszczeniu dźwiękiem. Kościoły mają to opanowane do perfekcji. Dzwony słychać w obrębie kilku kilometrów, kazania - kilkuset metrów. To jest nieprawdopodobna przemoc symboliczna. 


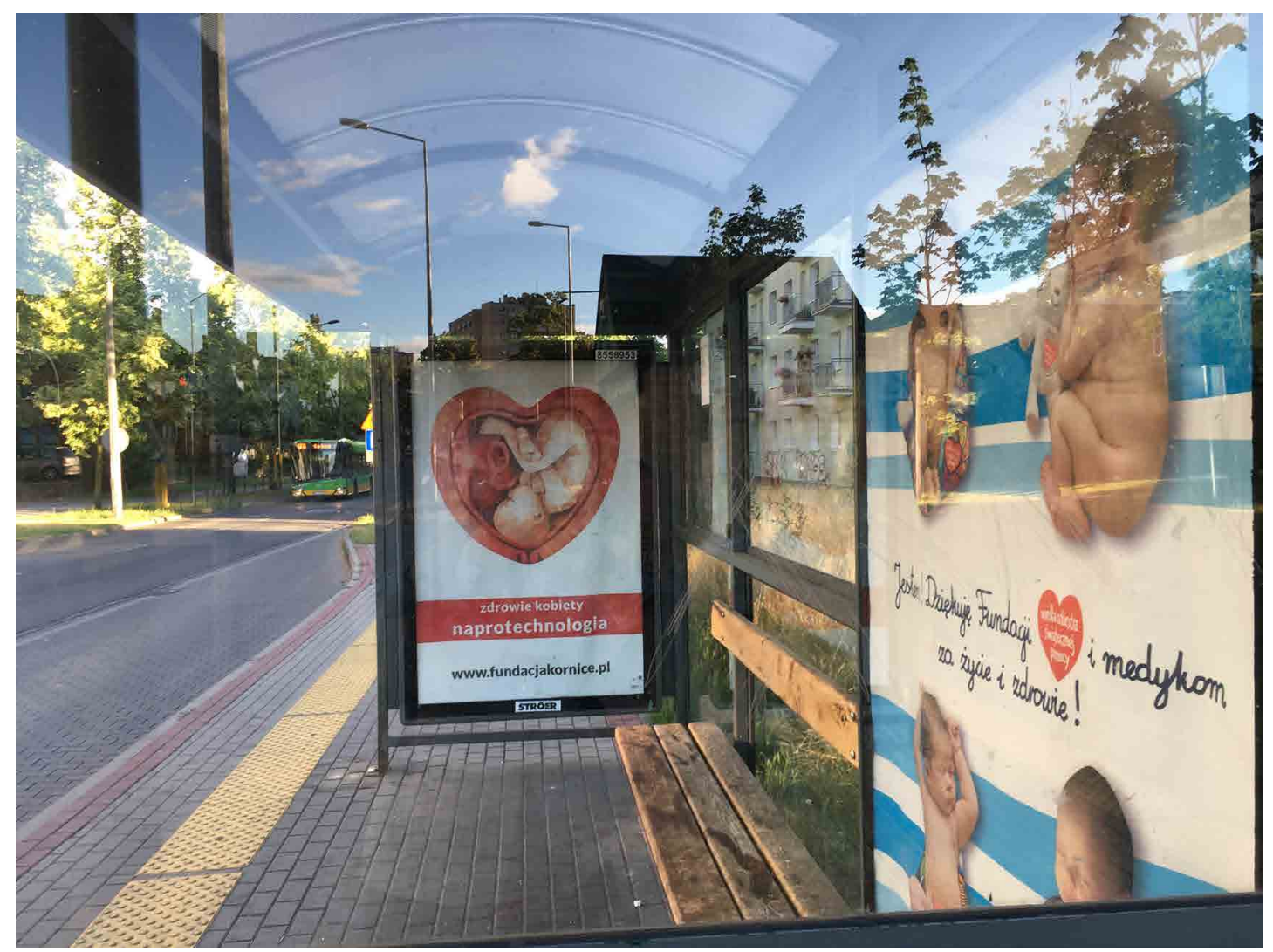

Fot. Anna Zawadzka

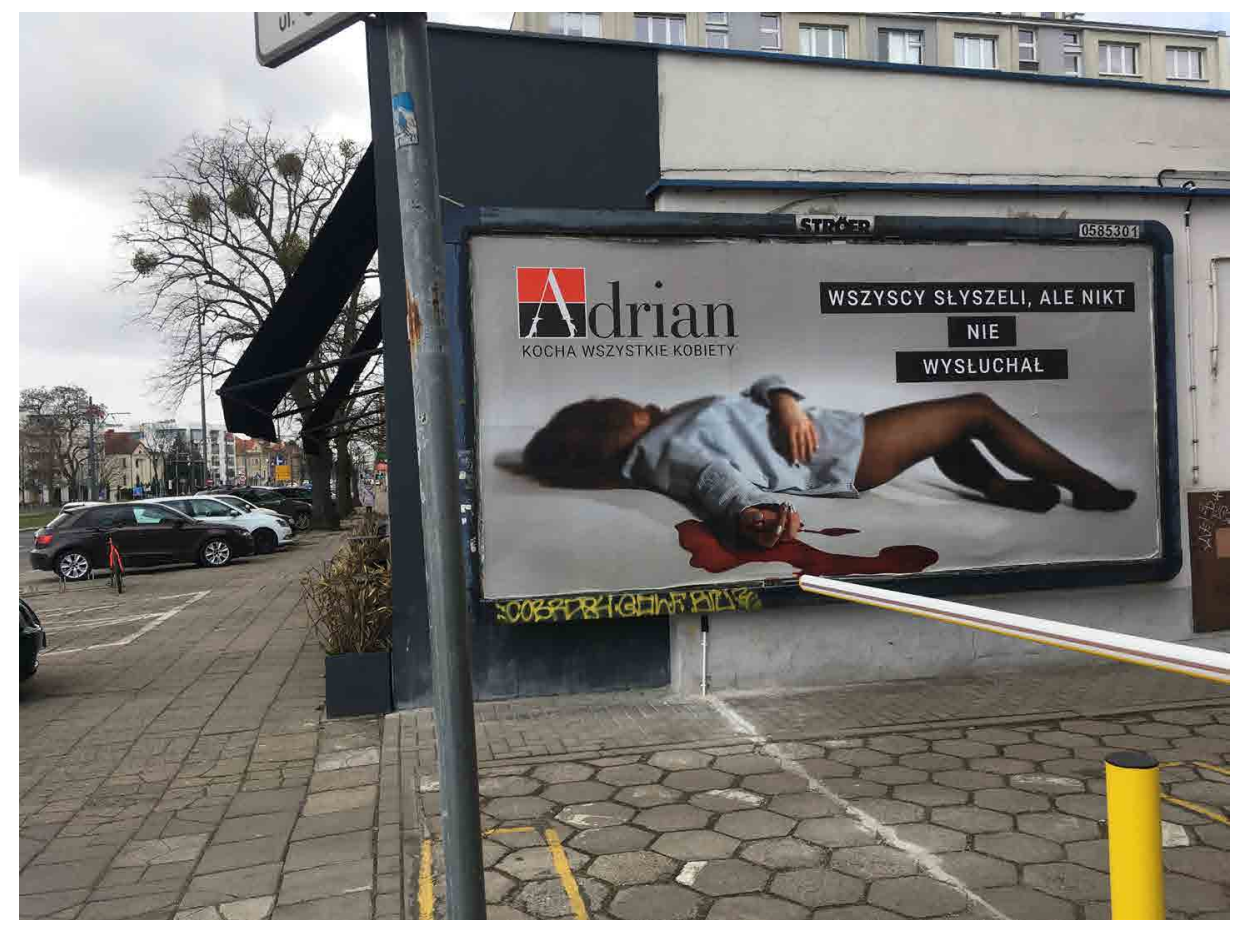

Fot. Anna Zawadzka 


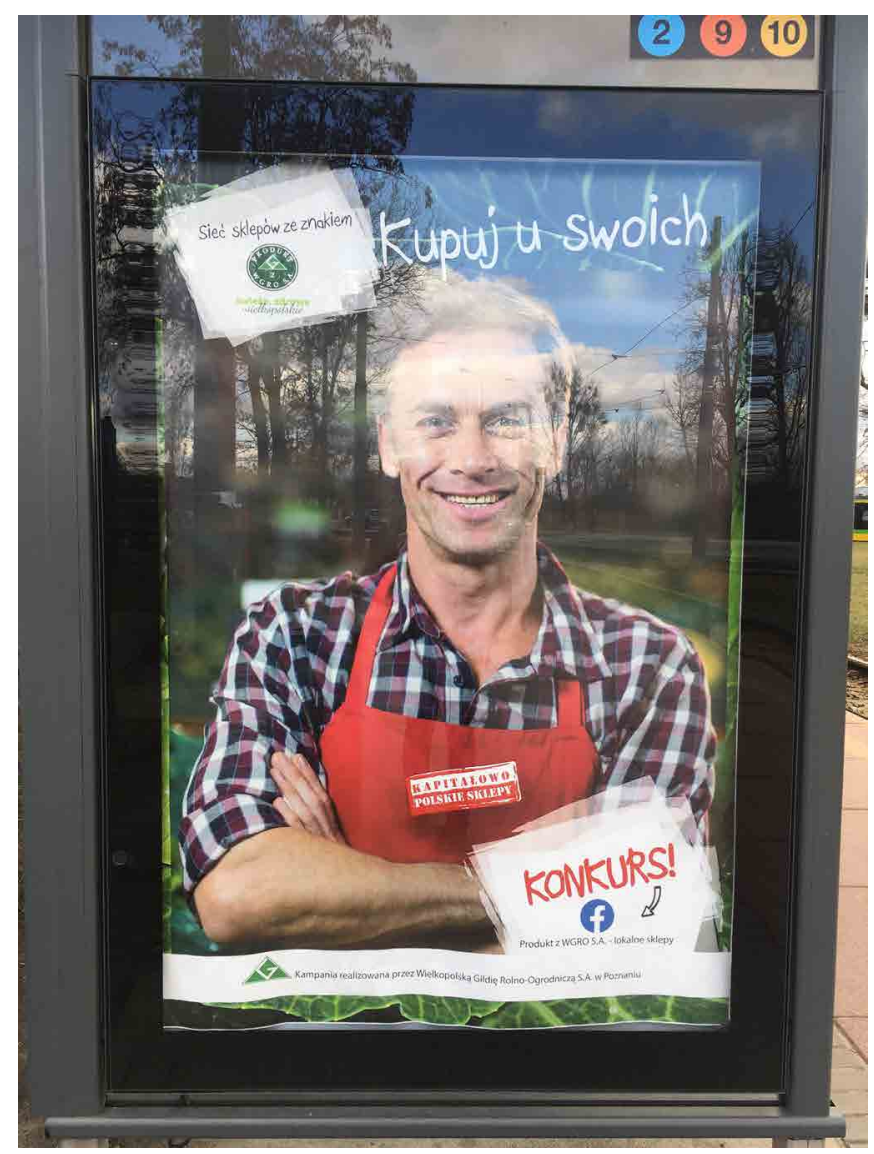

Fot. Anna Zawadzka

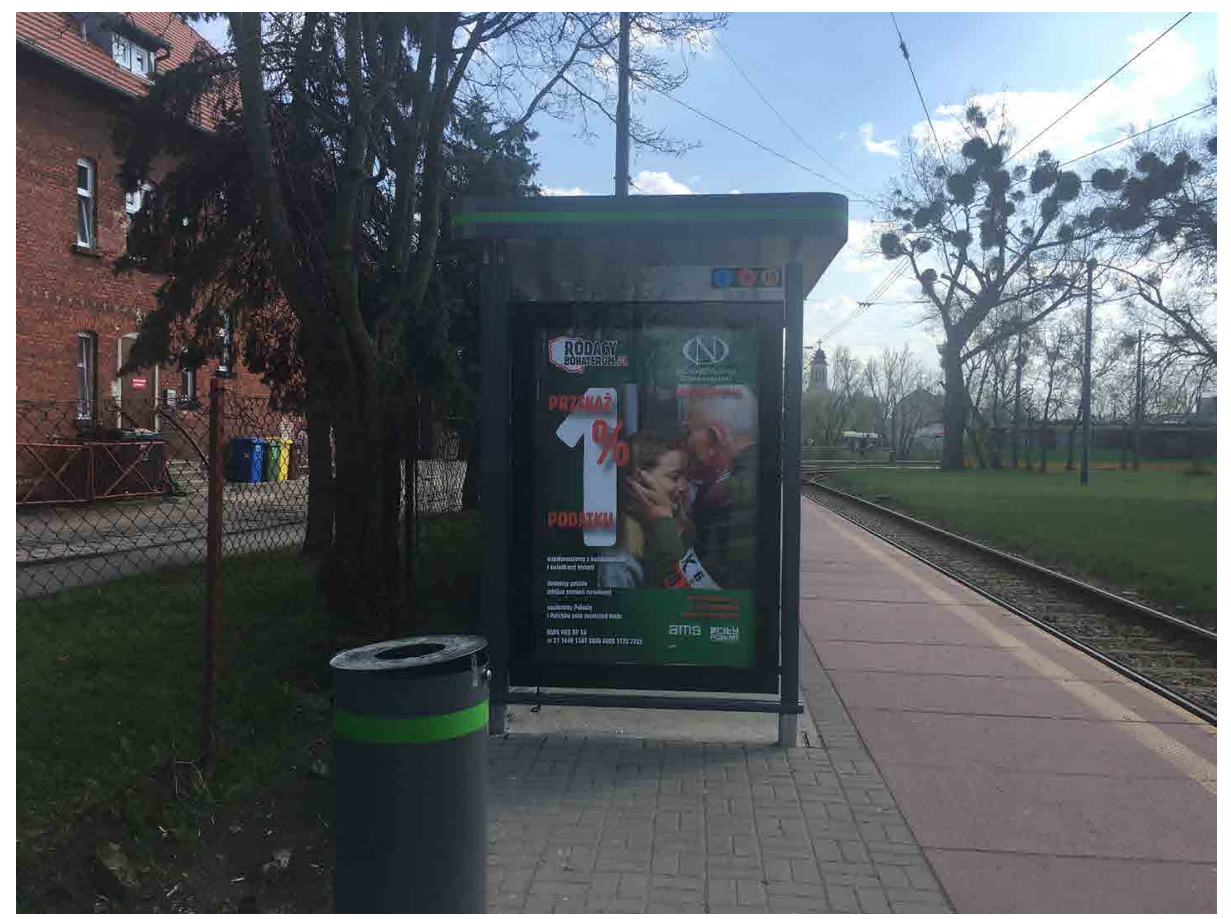

Fot. Anna Zawadzka 


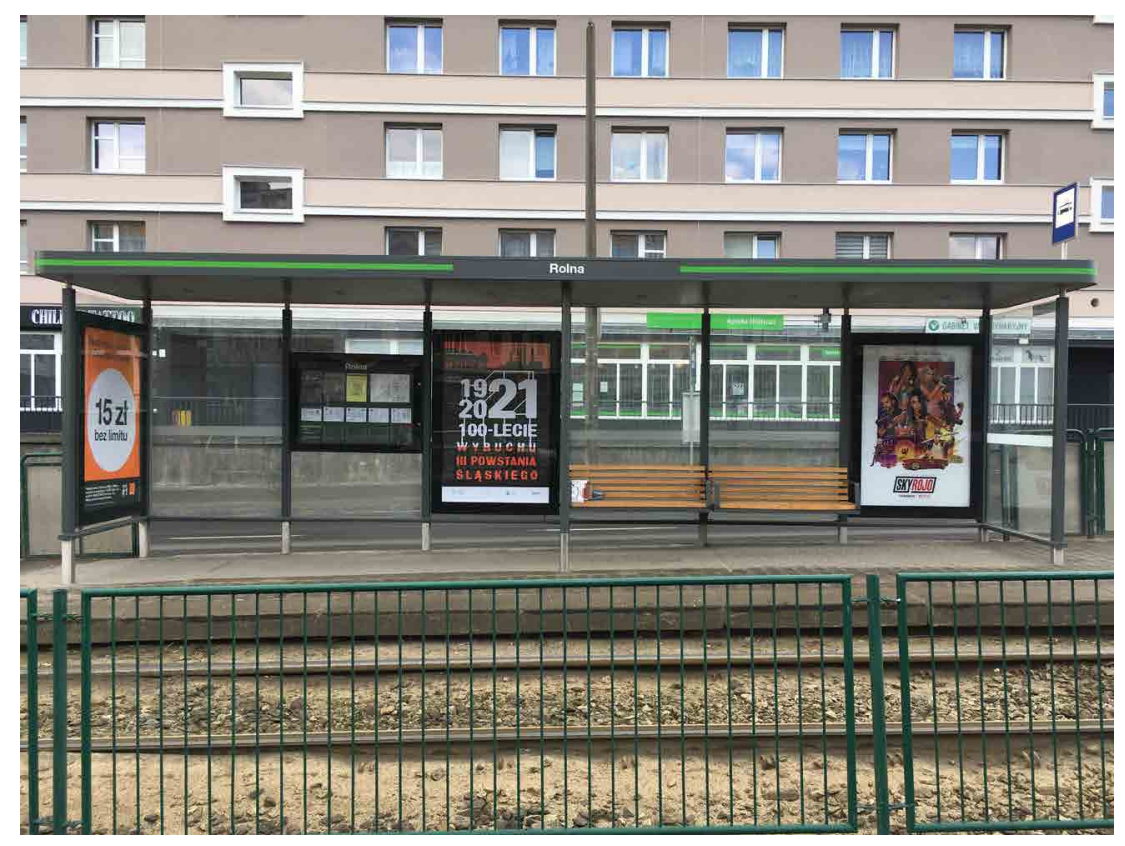

Fot. Anna Zawadzka

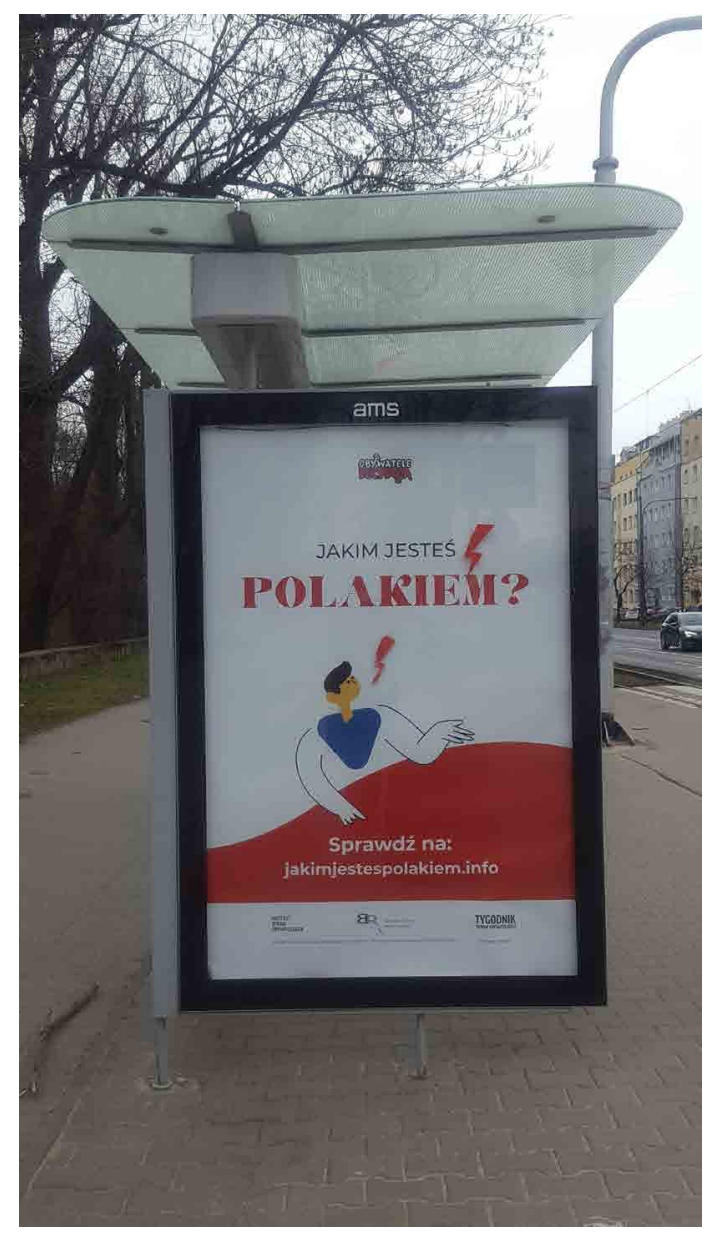

„Jakim jesteś Polakiem?” Plakat na przystanku

Berezyńska 01, Al. Waszyngtona, Warszawa,

kwiecień 2021 (fot. Katrin Stoll) 
A.Z.: Obserwacje Xawerego dotyczące przestrzennego antykomunizmu uzupełniłabym rozpoznaniami Jeleny Subotić. W książce Yellow Star, Red Star. Holocaust Remembrance after Communism (Subotić, 2019) szczegółowo opisuje ona proces usuwania znaków pamięci partyzantki antyfaszystowskiej z przestrzeni publicznej krajów postkomunistycznych: Chorwacji, Serbii, Litwy, Węgier, Ukrainy. Podobnie jak w Polsce zmieniano tam nazwy ulic, a pomniki rozbierano, wysadzano za pomocą ładunków wybuchowych lub zastępowano pomnikami faszystów: w Serbii czetników, w Chorwacji ustaszy, w Polsce Narodowych Sił Zbrojnych. Subotić uważa, że w wymienionych krajach obłąkańczy antykomunizm powoduje delegitymizację antyfaszyzmu, a wraz z nią następuje proces re-legitymizacji faszyzmu. Innymi słowy, delegitymizacja antyfaszyzmu była otwarciem wrót polityki głównego nurtu dla skrajnej prawicy. Tym samym Subotić stawia odpór popularnym w Europie opiniom, jakoby kraje byłego bloku wschodniego „nie dorosły do demokracji” z winy komunizmu, który produkować miał „człowieka podporządkowanego”, homo sovieticus, i dlatego dziś borykają się z populizmem. Jej zdaniem jest dokładnie odwrotnie: całkowite odrzucenie i demonizacja dorobku komunizmu uprawomocniło faszyzm.

Przygotowując się do naszej rozmowy, przeczytałam zaproponowane przez Katrin lektury: Marginality, Ethnicity and Penality in the Neoliberat City: an Analytic Cartography (Wacquant, 2014) oraz Territorial Stigmatization in the Age of Advanced Marginality Loïca Wacquanta (Wacquant, 2007). Pozwoliły mi one uporządkować wrażenia z kilkuletniego pobytu w Berlinie. Wrażenia te nie są oparte o lektury, wiedzę teoretyczną, badania, analizy, lecz o powolny proces nabywania kompetencji przestrzennej w nowym mieście. Wacquant pisze o rasowej i klasowej gettoizacji miast: są dzielnice „wstydliwe”, to znaczy takie, do których trudno się przyznać. Miasto releguje tam imigrantki/ów i ludzi biednych. Klasyczne przykłady to południowe Los Angeles czy podparyskie Saint-Denis. Myślę jednak, że ten opis już nie wystarcza. Przykład Berlina pokazuje, że jesteśmy na kolejnym etapie miejskiej segregacji. Dzielnice imigranckie i dzielnice biedy stają się, po pierwsze, miejscem turystyki orientalistycznej i klasowej, a po drugie alibi dla krajów i społeczeństw zachodnich, że są one tolerancyjne i otwarte, bo przecież przyjmują „obcych” i pozwalają im mieszkać „u siebie”. Faszystowska regulacja przestrzeni zostaje przysłonięta dyskursem o zbawczym „multi-kulti”.

Kiedy przyjeżdżałam do Berlina jako gość, nie zaglądałam za tę kurtynę. Kiedy tam zamieszkałam, stało się dla mnie jasne, że Berlin funkcjonuje sprawnie dzięki niskopłatnej pracy imigrantek i imigrantów. Są oni gettoizowani w kilku dzielnicach. Władze miasta o te dzielnice nie dbają. Nie robią tego również prywatni inwestorzy, np. gigantyczne firmy developerskie posiadające tam wiele nieruchomości. Wywóz śmieci, naprawa jezdni, stan chodników, zieleń miejska, sprzątanie klatek schodowych - wszystko to jest tam w zaniku. Dlaczego? Dlatego, że ludzi tam mieszkających i tak nie stać na to, by przenieść się do „lepszych”, to znaczy bardziej zadbanych części Berlina. Po pierwsze, nie mają na to środków, po drugie, nawet jak mają, to z obco brzmiącym nazwiskiem, 
brakiem paszportu UE lub nieznajomością języka niemieckiego nikt im tam mieszkania nie wynajmie. Na rasizmie korzysta więc zarówno miasto, jak i firmy prywatne. W efekcie tych kilka dzielnic jest przeludnionych. Duże rodziny mieszkają w klitkach, budynki są zaniedbane, windy popsute, trawniki zaśmiecone. Na moim kilkusetmetrowym podwórku było tyle szczurów, że doszczętnie zrujnowały kostkę brukową. Robiąc pod nią kanały, pofałdowały nawierzchnię do tego stopnia, że nie dało się po niej chodzić. Co na to mówią Niemcy? „Tam” jest tak brudno i trudno, bo mieszkają „tam” imigranci, to oni robią bałagan. Tymczasem jest dokładnie odwrotnie. Wykorzystując ekonomiczne i symboliczne upośledzenie mieszkańców, zarówno sektor publiczny, jak i prywatny, mają w głębokim poważaniu stan tych dzielnic i pozwalają sobie na ich skandaliczne zaniedbanie. Stowarzyszenie Kotti \& CO zrobiło badania wśród mieszkańców mojego osiedla, co najbardziej im przeszkadza w ich najbliższym otoczeniu (Clausen i in., 2018). Brak szkół, łatwy dostęp do narkotyków, hałas? Też. Ale przede wszystkim brud. W ankiecie brud wygrał bezapelacyjnie. Oczywiście sąsiedzi sprzątają na własną rękę. Mieszkańcy, na ile starcza im środków i sił, na własny koszt wyręczają państwo i kapitalistów.

Rasizm segregacji osiedlowej, o którym mówię, nie wymaga żadnych wysublimowanych narzędzi, by być widocznym. Dopiero w Berlinie zrozumiałam, na czym polegała dzielnica żydowska w Warszawie. Dopiero tam zobaczyłam na własne oczy, jak rasistowska może być struktura miasta. To jest jak w Stanach Zjednoczonych: wysiadasz z samolotu i natychmiast widzisz, że wszystkie najbardziej męczące, najniżej płatne i najmniej szanowane prace, zazwyczaj prace fizyczne, wykonują osoby nie-białe. Berlin ma wiele dzielnic zasobnych i ekskluzywnych. Jest w nich przestronnie, czysto, cicho i przede wszystkim przeraźliwie pusto. W dzielnicach imigranckich zaczyna się życie. A wraz z nim proces, którego Wacquant już nie opisał. Do dzielnic imigranckich ciągną bowiem studenci, turyści, lewicowcy. Bo tam jest kolorowo, egzotycznie, smacznie i tanio. Mieszkanie w tych dzielnicach staje się modne, towarzysko dystynktywne. Pozwala na samoidentyfikację jako osoby otwartej, tolerancyjnej, antyrasistowskiej. A jednocześnie stanowi doskonałe alibi dla strukturalnego rasizmu, który te dzielnice wytwarza. Neukölln i Kreuzberg służą dobremu mniemaniu całego Berlina o sobie. Katrin wspomniała, że czasopismo „Die Welt” nazwało Angelę Merkel „kanclerzem bez granic”. Niemcy lubią myśleć o sobie, że są „dojrzałą demokracją” („epizod” narodowego socjalizmu nie zaburza im zbytnio tej wizji), a już to, że Merkel „wpuściła uchodźców” - bo tak to jest nazywane - noszą niczym order. Niemiecka Willkommenskultur to odpowiednik polskiego filosemityzmu. Nie było dnia, bym w Berlinie nie usłyszała rasistowskiego komentarza pod adresem „Turków i Arabów”. W pracy notorycznie pytano mnie, „jak ty możesz tam mieszkać”. Ale to, że „oni” tam mieszkają, jest dowodem na to, że Niemcy nie są rasistami. Bo przecież pozwalają „im” tam mieszkać.

Chcę być dobrze zrozumiana: to ja jestem gentryfikacją. Prawdopodobnie wy też nią jesteście. Dla nas dzielnice imigranckie to atrakcyjne miejsca. I, jeśli jest się białą/biaŁym, bardzo bezpieczne. Jeśli jest w nich wysoki odsetek przemocy, to ona dzieje się 
między jednostkami i grupami dyskryminowanymi. Na sytuacje ryzykowne wobec białych nikt tam sobie nie pozwoli, bo policja, urzędy, sądy będą orzekać na niekorzyść „obcych”. Jeśli jesteś obiektem zainteresowania policji, nie będąc Niemcem, nie będąc osobą białą i nie mając paszportu Unii Europejskiej, to nie ryzykujesz konfrontacji z organami władzy. W warunkach strukturalnego rasizmu na przemoc wobec białych pozwolić sobie mogą wyłącznie biali.

M.S.: Polacy również miewają znakomite mniemanie o sobie. Wrocław jest tego świetnym przykładem. Lansowana od kilku lat strategia marketingowa miasta oparta jest na haśle: „Wrocław jako miasto spotkań”. Poniekąd sfalsyfikowaliśmy to hasło w ramach zainicjowanych przez Stowarzyszenie Nomada badań jakościowych na temat przemocy motywowanej nienawiścią, głównie przemocy rasistowskiej (Starnawski \& Pawlik, 2012). W „mieście spotkań” mieliśmy już rozkwit Narodowego Odrodzenia Polski, atak narodowców na Zygmunta Baumana przed wykładem na Uniwersytecie Wrocławskim w 2013 roku, akcję „Tramwaj zwany nacjonalizmem” NOP-u, wystąpienia Międlara, spalenie kukły „Żyda” na Rynku. Wrocław oferuje także jedyną nacjonalistyczną alternatywę dla warszawskiego Marszu Niepodległości: Marsz Patriotów, na który jeszcze do niedawna, co roku, 11 listopada przychodziło po kilka tysięcy osób.

K.M.: Berlin uchodzi za stolicę Europy. Esencję europejskiego dobra. Zastanawia mnie moment, w którym orientujemy się, że z tym modelem jest coś nie w porządku. Jakie warunki muszą zaistnieć, by zacząć o tym mówić? Twoja ocena Berlina, Aniu, jako imigrantki, jest niecenzuralna. Nie masz prawa tego wszystkiego mówić. Robiąc to, nadużywasz gościnności. Powinnaś chwalić.

K.S.: Jedenaście lat temu Thilo Sarrazin, socjaldemokrata, szef Bundesbanku, wydat książkę Deutschland schafft sich ab [Niemcy same się likwidują] (Sarrazin, 2010). Ta „samolikwidacja" to, jego zdaniem, efekt zbyt liberalnej polityki migracyjnej. Autor pisze, kto ma, a kto nie ma prawa żyć w Niemczech. Według Sarrazina „Turcy i Arabowie” w Berlinie nie „mają żadnej produktywnej funkcji poza handlem owocami i warzywami” (cyt. za: Gremliza, 2016, s. 66). „Nie podlega dyskusji”, jak pisał redaktor naczelny czasopisma „konkret” Hermann L. Gremliza, że „kto tak mówi, jest rasistą, nawet gdy większość autochotonicznych typowych Niemców (Teutonen) [...], wezwana na dywanik, w ogóle nie wie, czego się od niej chce" (Gremliza, 2016, ss. 66-70). Książka Sarrazina szybko stała się bestsellerem. Autor do 2020 roku był członkiem SPD. To są elity niemieckie. Przyklasnęły one także obrazowi islamskiego zagrożenia, jaki narysował Sarrazin. Jego zdaniem koniec Niemiec nadchodzi wraz z muzułmanami, którzy „produkują permanentnie nowe dziewczynki w chustach" (cyt. za: Gremliza, 2016, s. 66). 
M.S.: Upierałbym się jednak przy moich naiwnych pytaniach. 0 poruszonych przez was sprawach można mówić bez pojęcia faszyzacji. Gentryfikacja, prekaryzacja, rewitalizacja - nie jest dla mnie oczywiste, jak się mają do faszyzacji. Xawery wspomniał o neoliberalizmie. Neoliberalizm jako rama krytyczna już nie wystarczy. Korporacje, które są głównym podmiotem sprawczym neoliberalizmu, jawią się nieco w kontrze do różnych procesów, które nazwalibyśmy elementami faszyzacji. Ikea zwolniła pracownika-homofoba. Zalando, Facebook, Twitter - w wymiarze marketingowym wszystkie te platformy stawiają na inkluzywność, są prorównościowe. Być może jest to zasłanianie wyzysku ładnym, na przykład tęczowym, sztafażem. Nie jestem tak naiwny, by zaraz te koncerny pokochać, ale tutaj widać, że logika akumulacji kapitału nie jest jednoznacznie sprzężona z faszyzacją. Z kolei przedsiębiorca, który inwestuje w billboardy antyaborcyjne, poniekąd „wyrzuca” pieniądze, które mógłby zainwestować w firmę.

Jeśli chodzi o segregację terytorialną opisaną przez Loïca Wacquanta, myślę, że we współczesnym kontekście polskim ten model ma duże ograniczenia. W Polsce nie ma typowych dzielnic imigranckich. Jedyna grupa etniczna, która doświadcza w Polsce jednoznacznego wykluczenia terytorialnego, to Romowie. Segregacja ma tutaj jednak charakter bardziej klasowy. Ludzie o niskim statusie społecznym - w tym Romowie - mieszkają w określonych rejonach miasta. Nie stać ich na to, żeby zamieszkać gdzie indziej, stąd przestrzenna koncentracja. Kiedy formalno-prawnie nie ma segregacji, wtedy decyduje o niej podział pracy, wyzysk, siła nabywcza. Aktywiści ruchów miejskich podnoszą wątek gentryfikacji, tymczasem chodzi tu raczej o stosunki pracy: wyzysk siły roboczej ograniczający siłę nabywczą. Ten aspekt powinien być włączony do analiz nierówności miejskich.

A.Z.: Na Zachodzie segregacja przestrzenna jest również klasowa. Tyle że tam klasa ma widoczność rasową. Te dwa piętna nawzajem się wzmacniają. W Polsce nie ma gett etnicznych czy rasowych, ponieważ polskie władze, przy hojnej pomocy polskiego spoŁeczeństwa, w ogóle nie dopuszczają do tego, by tu jakieś mniejszości były.

M.S.: W Polsce jest duża populacja emigrantów zarobkowych z Ukrainy. Podlegają oni nieraz napiętnowaniu na tle etnicznym czy swoistemu „urasowieniu” (podobnie jak Polacy i inne grupy pochodzenia wschodnioeuropejskiego w krajach zachodnich, np. w Wielkiej Brytanii), a jednak nie są relegowani do gett. W tym kontekście warto wspomnieć o PRL-owskich blokowiskach. Z założenia były one anty-segregacyjne: mieszkania przydzielano w nich tak, by w jednym bloku mieszkały osoby z różnych warstw - na przykład w blokach zakładowych mieszkały rodziny robotnicze i rodziny kadry zarządzającej. Trzydzieści lat kapitalizmu na pewno tę sytuację zmieniło, trzeba by jednak zbadać, czy wieloklasowość blokowisk całkowicie zniknęła. Poza ewidentnymi przykładami osiedli grodzonych, w polskich miastach nadal są przestrzenie klasowo nieoczywiste.

SLH 10/2021 | s. 30 z 34 
K.M.: Może nie ma dziś w Polsce gett, ale są miejsca, które mają charakter getta. W Warszawie takimi miejscami są hostele turystyczne, w których, z powodów ekonomicznych i na mocy strategii obronnej, decydują się mieszkać imigranci. Państwo polskie udziela zezwoleń na pracę osobom z Azji Centralnej, Indii i Pakistanu. Te osoby automatycznie lądują na najniższym możliwym statusie. Pracują bez umowy o pracę, np. jako kurierzy, mieszkają w hostelach, bo tam, będąc z innymi, mogą czuć się bezpieczniej. To jest sposób prześladowanej mniejszości na ograniczanie przemocy. Do hostelu tak łatwo nie wtargnie grupa nacjonalistów i ich nie pobije, tymczasem na klatce schodowej bloku czy kamienicy zrobi to bez przeszkód. To tylko przykład, takich miejsc-gett we współczesnej Polsce jest więcej. Gdyby proporcje ilościowe były inne, proces przedwojennej gettoizacji prędko by się odtworzyt.

\section{Bibliografia}

Agence France-Presse in Copenhagen. (2021, marzec 17). Denmark plans to limit „non-western” residents in disadvantaged areas. The Guardian. https://www.theguardian.com/world/2021/mar/17/denmark-plans-to -limit-non-western-residents-in-disadvantaged-areas

Barrot, J. (2010). Faszyzm i antyfaszyzm: Analiza liberalnej i lewicowej obsesji na punkcie faszyzmu i antyfaszyzmu oraz roli robotników w międzynarodowym sprzeciwie wobec niego. Przegląd Anarchistyczny, 2010(10). http://www.przeglad-anarchistyczny.org/faszyzm-w-demokracji/231-faszyzm-i-antyfaszyzm

Biespałowa, J. (2017,wrzesień 29). Trzcianka 2017:Zaginęło 56żołnierzy Armii Czerwonej.Sputnik Polska. https://pl.sputniknews.com/opinie/201709296377302-sputnik-trzcianka-2017-mauzoleum-armia-czerwona-zolnierze/

Błoński, J. (1994). Walhalla Wawel. W J. Błoński \& J. Popiel (Red.), Studia o dramacie i teatrze Stanisława Wyspiańskiego. Baran i Suszczyński.

Borejsza, J. W. (1979). Wstęp. W J. W. Borejsza (Red.), Faszyzmy europejskie (1922-1945) w oczach wspótczesnych i historyków (ss. 5-40). Czytelnik.

Bryk, A. (1990). The hidden complex of the Polish mind: Polish-Jewish relations during the Holocaust. W A. Polonsky (Red.), My brother's keeper: Recent Polish debates on the Holocaust (pp. 161-184). Routledge.

Cembrowska, A. (2021, marzec 8). „Jak go stać, to niech robi, co chce”: Oto kto i za ile zalewa Polskę serduszkowymi plakatami. na:Temat. https://natemat.pl/342511,antyaborcyjna-akcja-billboardowa-kto-za-tym-stoi-ile-moze-kosztowac\#

Clausen, M., Greve, G., Simon, C., Thodos, G., Lüth, L., \& Willem, J. (2018). Re-Kommunalisierung Plus | Modellprojekt am Kottbusser TorBerlin. Kotti-Coop e.V. https://kottbussertor.org/index.html

Czuchnowski, W. (2003, marzec 16). Wystawa zdjęć rasistowskich napisów na murach. wyborcza.pl / Kraków. https://krakow.wyborcza.pl/krakow/7,44425,1375435.html

di Cesare, D. (2020). Resident foreigners: A philosophy of migration (D. Broder, Tłum.). Polity Press.

Die Stadt ohne Juden Muslime Flüchtlinge Ausländer. (b.d.). Filmarchiv Austria. https://www.filmarchiv.at/program/exhibition/die-stadt-ohne/

Eatwell, R. (1999). Faszyzm: Historia (T. Oljasz, Tłum.). Dom Wydawniczy Rebis.

Ekielski, W., \& Wyspiański, S. (1908). Akropolis: Pomysł zabudowania Wawelu. Drukarnia Uniwersytetu Jagiellońskiego.

Gimnazjalistka. (2002). Holocaust - czemu nie. Stowo Żydowskie - Dos Jidisze Wort, 2002(3-4(263-264)), 18-19. 
Głowacka-Sobiech, E. (2003). Twórcy polskiego skautingu - Olga i Andrzej Małkowscy. Wydawnictwo Poznańskie.

Głowiński, M. (1990). Konstelacja Wyzwolenia. Pamiętnik Literacki, 81(2), 35-77.

Gremliza, H. L. (2016). Haupt- und Nebensätze. Suhrkamp Verlag.

Griffiths, R. (2005). Fascism. Continuum.

Innenminister Seehofer zu Migration: „Mutter aller politischen Probleme”. (2018, wrzesień 6). Die Tageszeitung: Taz. https://taz.de/Innenminister-Seehofer-zu-Migration/!5533764/

Janicka, E. (2014-2015). Pamięć przyswojona: Koncepcja polskiego doświadczenia zagłady Żydów jako traumy zbiorowej w świetle rewizji kategorii świadka. Studia Litteraria et Historica, 2014-2015(3-4), 148227. https://doi.org/10.11649/slh.2015.009

Janion, M. (2009). Aneks o Zagładzie. W M. Janion, Bohater, spisek, śmierć: Wykłady żydowskie (ss. 63-76). W.A.B.

Kajta, J. (2020). Młodzi radykalni? O tożsamości polskiego ruchu nacjonalistycznego i jego uczestników. Zakład Wydawniczy „Nomos”.

Klimczak, K. (2018, październik 23). Jesienne remonty w parku Skaryszewskim. Warszawa: Oficjalny portal miasta. Pobrano 14 czerwca 2021, z http://www.um.warszawa.pl/de/aktualnosci/jesienne-remonty-w-parku-skaryszewskim

kn. (2019, sierpień 6). Saska Kępa. Obalony pomnik Zygmunta Berlinga nie wróci na swoje miejsce. Powodem ustawa dekomunizacyjna. Metro Warszawa. https://metrowarszawa.gazeta.pl/metrowarszawa/7,141637,25065050,saska-kepa-obalony-pomnik-zygmunta-berlinga-nie-wroci-na-swoje.html

Koalicja Antyfaszystowska. (2019). Za Wolność Waszą i Nasza! Facebook. Pobrano 14 czerwca 2021,z https://www. facebook.com/events/701230060379559/?acontext=\%7B\%22event_action_history\%22\%3A[\%7B\%22surface\%22\%3A\%22page\%22\%7D]\%7D

Kolankiewicz, L. (1995). Notatki po spektaklu: O candonblé da Bahia (5). Dialog: Miesięcznik Związku Literatów Polskich, 40(5), 122-137.

Korwek, B. (2007, kwiecień 5). Roman Dmowski. Powiat Łomżyński.pl. Pobrano 27 czerwca 2021, z http:// powiatlomzynski.pl/index.php?wiad=652

List otwarty Prezydenta RP. (2002). Prezydent.pl. Pobrano 27 czerwca 2021, z https://www.prezydent.pl/archiwalne-aktualnosci/rok-2002/art,31,list-otwarty-prezydenta-rp.html

lulu. (2019, marzec 30). Ekipa Trzaskowskiego zwalnia dyrektora od zieleni. W tle konflikt w ratuszu. „Nie wykonywatem poleceń". Metro Warszawa. https://metrowarszawa.gazeta.pl/metrowarszawa/7,141637,24599319,ekipa-trzaskowskiego-zwalnia-dyrektora-od-zieleni-w-tle-konflikt.html

Lutosławski, W. (1897). The origin and growth of Plato's logic with an account of Plato's style and of the chronology of his writings. Longmans, Green.

Lutosławski, W. (1903). Początki Eleusis. Eleusis: Czasopismo Elsów, 1, 269-296.

Lutosławski, W. (1907). Joga czyli rozwój potęgi woli przez psychofizyczne ćwiczenia (cz. I). Eleusis: Czasopismo Elsów, 2, 79-114.

Lutosławski, W. (1908). Joga czyli rozwój potęgi woli przez psychofizyczne ćwiczenia (cz. II). Eleusis: Czasopismo Elsów, 3-4, 178-219.

Lutosławski, W. (1909). Rozwój potęgi woli przez psychofizyczne ćwiczenia według dawnych aryjskich tradycji oraz własnych swoich doświadczeń podaje do użytku rodaków. Gebethner i Wolff.

Mapa dotacji: „Zagospodarowanie Placu Pocztowego wraz z utworzeniem Centrum Integracji Społecznej oraz zagospodarowanie terenu Targowiska Miejskiego wraz z terenami przyległymi”. (b.d.). Pobrano 14 czerwca 2021, z https://mapadotacji.gov.pl/projekty/790930/?lang=en

Matyjaszek, K. (2019). Produkcja przestrzeni żydowskiej w dawnej i wspótczesnej Polsce. Towarzystwo Autorów i Wydawców Prac Naukowych „Universitas”.

Metz, M., \& Seeßlen, G. (2016). Hass und Hoffnung: Deutschland, Europa und die Flüchtlinge. Bertz + Fischer. 
Osiński, Z. (1993). Grotowski wytycza trasy: Studia i szkice. Pusty Obłok.

Padot, R. (1982). Filozofia religii polskiego modernizmu. Wydawnictwo Literackie.

Pieczyńska-Chamczyk, M. (2020, grudzień 16). Centrum Integracji Społecznej otwarte. asta24.pl. Pobrano 14 czerwca 2020, z https://www.asta24.pl/2020/12/16/centrum-integracji-spoleczne-otwarte

Płuska, I. (2009). Konserwacja romańskiej krypty św. Leonarda pod katedrą wawelską. Budownictwo: Czasopismo Techniczne, 2009(6(106)), 261-268.

Puzyna, K. (1957-1958). Powrót Wyspiańskiego. W Stanisław Wyspiański, „Wyzwolenie” [Program Teatru Narodowego], (ss. 6-16). Teatr Narodowy.

Sarrazin, T. (2010). Deutschland schafft sich ab: Wie wir unser Land aufs Spiel setzen. Deutsche Verlagsanstalt.

Seeßlen, G. (2020). Der neue Faschismus und der Weg dorthin: Eine kulturpolitische Einordnung [Wykład wygłoszony na Uniwersytecie w Paderborn, 19 maja 2020]. https://www.on-data-driven-armament.net/\#programm

Stańczyk, X. (2019, kwiecień 28). Patriotyczny antyfaszyzm i inne sprzeczności. Lewica.pl. http://lewica.pl/ index.php?id=32103\&tytul=Xawery-Sta\%F1czyk:-Patriotyczny-antyfaszyzm-i-inne-sprzeczno\%B6ci

Starnawski, M., \& Pawlik, K. (2012). Masz problem? Przemoc motywowana nienawiścia we Wrocławiu: Raport na podstawie badań przeprowadzonych na przełomie 2010/2011 roku. NOMADA Stowarzyszenie na Rzecz Integracji Społeczeństwa Wielokulturowego.

Subotić, J. (2019). Yellow star, red star: Holocaust remembrance after communism. Cornell University Press. https://doi.org/10.7591/9781501742415

Swiridow, L. (2019, październik 9). Zbezczeszczony cmentarz w Trzciance: będzie proces. Sputnik Polska. https:// pl.sputniknews.com/polska/2019100911165933-sputnik-zbezczeszczony-cmentarz-w-trzciance-bedzie -proces-Kursk/

Szostak, V. (2011, styczeń 7). Przypadki Sofii Casanovy. Gazeta Wyborcza / Wysokie Obcasy.

Szpala, I. (2013, listopad 27). Zostawić czy usuną́ pomnik Śpiących? Wyniki nowego sondażu. wyborcza.pl / Warszawa. https://warszawa.wyborcza.pl/warszawa/1,54420,15029940,Zostawic_czy_usunac_pomnik_Spiacych_Wyniki_nowego.html

Traverso, E. (2014). Historia jako pole bitwy: Interpretacja przemocy w XX wieku (Ś. F. Nowicki, Tłum.). Instytut Wydawniczy Książka i Prasa.

Urzykowski,T. (2018, październik 17). Burza radziecki pomnik w parku Skaryszewskim. „Rozbiórka wynika z ustawy dekomunizacyjnej”. wyborcza.pl / Warszawa. https://warszawa.wyborcza.pl/warszawa/7,54420,24056714,burza-radziecki-pomnik-w-parku-skaryszewskim.html

Wacquant, L. (2007). Territorial stigmatization in the age of advanced marginality. Thesis Eleven, 91(1), 66-77. https://doi.org/10.1177/0725513607082003

Wacquant, L. (2014). Marginality, ethnicity and penality in the neo-liberal city: An analytical cartography. Ethnic and Racial Studies, 37(10), 1687-1711. https://doi.org/10.1080/01419870.2014.931991

Wełyczko, M. (2002, styczeń 21). Gimnazjalistka oskarża. Przegląd, 2002(3). https://www.tygodnikprzeglad. $\mathrm{pl} /$ gimnazjalistka-oskarza

Wyspiański, S. (1970). Wyzwolenie. Zakład Narodowy im. Ossolińskich. 


\section{Decommunisation - Fascism without Fascists: \\ Konrad Matyjaszek, Xawery Stańczyk, Marcin Starnawski, Katrin Stoll and Anna Zawadzka discuss the Fascization of Space}

Abstract: Are there fascizizing ways to look at public space and aesthetics? If so, how do they manifest themselves? What characterizes the fascization of space? How and where can you recognize it? How do architecture and symbols in public space contribute to fascization of daily life? One of them is a policy of cleansing and rhetoric about recovering after an imaginary foreign domination or invasion. The aim of this conversation is to elucidate the concept of the fascization of public space. The discussants do this by drawing on examples from the history of Poland and Germany as well as the present-day situation in both countries. They also consider how we can clarify the category of fascization in order to distinguish this process from other phenomena such as nationalism.

Keywords: fascism; fascization; organization of space; anticommunism; Poland; Germany

Article No. 2598

DOI: $10.11649 /$ slh.2598

Citation: Matyjaszek, K., Stańczyk, X., Starnawski, M., Stoll, K., \& Zawadzka,A. (2021). Dekomunizacja, czyli faszyzm bez faszystów: O faszyzacji przestrzeni rozmawiają Konrad Matyjaszek, Xawery Stańczyk, Marcin Starnawski, Katrin Stoll i Anna Zawadzka (A. Zawadzka, Ed.). Studia Litteraria et Historica, 2021(10), Article 2598. https://doi.org/10.11649/slh.2598

This is an Open Access article distributed under the terms of the Creative Commons Attribution 3.0 PL License, which permits redistribution, commercial and non-commercial, provided that the article is properly cited. http://www.creativecommons.org/licenses/by/3.0/pl (c) The Author(s) 2021

Publisher: Institute of Slavic Studies, Polish Academy of Sciences, Warsaw, Poland Author: Konrad Matyjaszek, Institute of Slavic Studies, Polish Academy of Sciences, Warsaw, Poland ORCID: https://orcid.org/0000-0002-0236-4524

Correspondence: konrad.matyjaszek@ispan.waw.pl Author: Xawery Stańczyk, University of Lodz; Statistics Poland, Lodz-Warsaw, Poland ORCID: https://orcid.org/0000-0003-0042-0016

Correspondence: xawery.stanczyk@gmail.com

Author: Marcin Starnawski, University of Lower Silesia, Wrocław, Poland

ORCID: https://orcid.org/0000-0002-7536-3979

Correspondence: marcinstarnawski@poczta.fm

Author: Katrin Stoll, Friedrich Schiller University, Jena, Germany

ORCID: https://orcid.org/0000-0001-9928-4880

Correspondence: katrin.stoll@uni-jena.de

Author \& Editor: Anna Zawadzka, Institute of Slavic Studies, Polish Academy of Sciences, Warsaw, Poland

ORCID: https://orcid.org/0000-0002-6043-3321

Correspondence: anna.zawadzka@ispan.waw.pl

The preparation of this work was self-financed by the authors.

Competing interests: A.Z. is the editor-in-chief of the journal. K.M. is the deputy editor of the journal. K.S. is a member of the Editorial Team of the journal and the editor-in-charge of this issue. X.S. \& M.S. are members of the Editorial Team of the journal.

Publication history: Received: 2021-06-28; Accepted: 2021-10-07; Published: 2021-12-31 